\title{
Late Triassic to Early Cretaceous palynostratigraphy of Kong Karls Land, Svalbard, Arctic Norway, with correlations to Franz Josef Land, Arctic Russia
}

\author{
Morten Smelror ${ }^{1}$, Geir Birger Larssen ${ }^{2}$, Snorre Olaussen ${ }^{3}$, Arnfinn Rømuld ${ }^{4}$ \\ \& Robert Williams ${ }^{5}$ \\ ${ }^{1}$ Geological Survey of Norway, P.O. Box 6315 Torgarden, NO-7491 Trondheim, Norway \\ ${ }^{2}$ Lundin Norway AS, P.O. Box 794, NO-9488 Harstad, Norway \\ ${ }^{3}$ Department of Arctic Geology, The University Centre in Svalbard (UNIS), P.O. Box 156, NO-9171 Longyearbyen, Norway \\ ${ }^{4}$ Equinor ASA, Forusbeen 50, NO-4035 Stavanger, Norway \\ ${ }^{5}$ Norwegian Petroleum Directorate, P.O. Box 600, NO-4003 Stavanger, Norway
}

E-mail corresponding author (Morten Smelror): Morten.Smelror@ngu.no

The Upper Triassic, Jurassic and Lower Cretaceous succession on Kong Karls Land contains common to abundant, well preserved, marine and terrestrial palynomorphs. The palynological assemblages suggest a Norian age for the Flatsalen Formation, which comprises the oldest deposits exposed on the islands. The overlying Svenskøya Formation is dated as Norian/?Rhaetian to Early Toarcian. There are possible depositional breaks at the base of and within this formation. The overlying Kongsøya Formation is dated as Late Toarcian-Aalenian. There is no evidence of exposed Bajocian deposits on Kong Karls Land. The oldest, transgressive deposits of the Agardhfjellet Formation are dated as Bathonian, while the youngest part of this formation is of Kimmeridgian age. The oldest Cretaceous deposits exposed on Kong Karls Land are ValanginianHauterivian condensed carbonates assigned to the Tordenskjoldberget Member (Klippfisk Formation). Directly overlying the condensed unit are Upper Barremian, or possibly lowermost Aptian, marine shales of the Kolje Formation equivalent. The youngest rocks preserved on Kong Karls Land are fluvial deposits of the Hårfagrehaugen Member (Helvetiafjellet Formation) and the Kong Karls Land basaltic lava flows. The terrestrial palynomorphs found in the Håfagrehaugen Member support a latest Barremian to Aptian age for the Helvetiafjellet Formation, as suggested by the $\mathrm{U}-\mathrm{Pb}$ geochronology.

Keywords: Mesozoic, stratigraphy, palynology, Svalbard

Received 07. March 2017 / Accepted 16. March 2018 / Published online 18. January 2019

\section{Introduction}

Marine and terrestrial palynomorphs are established as important biostratigraphic tools for dating and correlation of Upper Palaeozoic, Mesozoic and Lower Tertiary strata on Svalbard and the Barents Shelf. The present paper presents palynostratigraphic information from the Norian to Barremian formations on Kong Karls Land, a group of islands in the eastern Svalbard archipelago. Svalbard is an uplifted and exposed part of the Barents Shelf and the archipelago serves as an important reference area for the contemporaneous successions in the Barents Sea targeted for petroleum exploration (Figs. 1,2). Studies of the Mesozoic succession of Kong Karls Land commenced already in the late 1890s (Nathorst, 1901, 1910), and were succeeded by a series of expeditions in the following century. In addition to the published record of investigations, significant amounts of data are stored in unpublished reports from several scientific expeditions, field surveys and offshore and onshore exploration drillings.

The present paper concerns material collected during an expedition to Kong Karls Land arranged by Statoil 


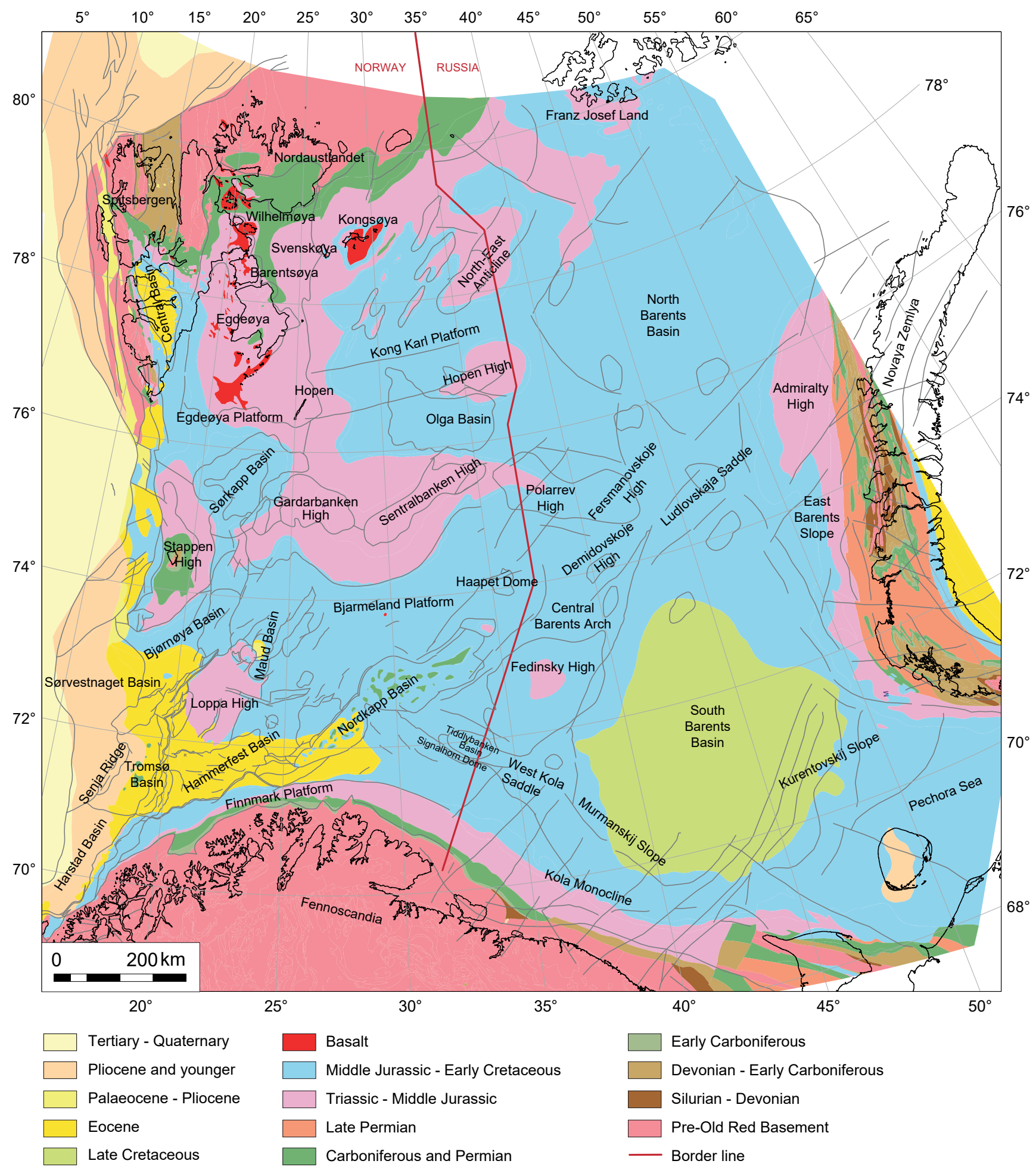

Figure 1. Generalised bedrock map of the Barents Sea and adjacent islands and land areas.

in 1984 and the Norwegian Petroleum Directorate in 1993 (Fig. 2; Larssen et al., 1995; Olaussen et al., 2018). Details on the structural setting, basin development, depositional environment and sequence stratigraphy are given in Olaussen et al. (2018). In addition to information from the 1993 expedition, we here refer to unpublished palynostratigraphic data analysed by Fiksdal (1988) from a section on Kongsøya sampled by M. Edwards. The palynostratigraphic data from Kong Karls Land are used for correlations with the contemporaneous succession in Franz Josef Land and the Barents Sea. 


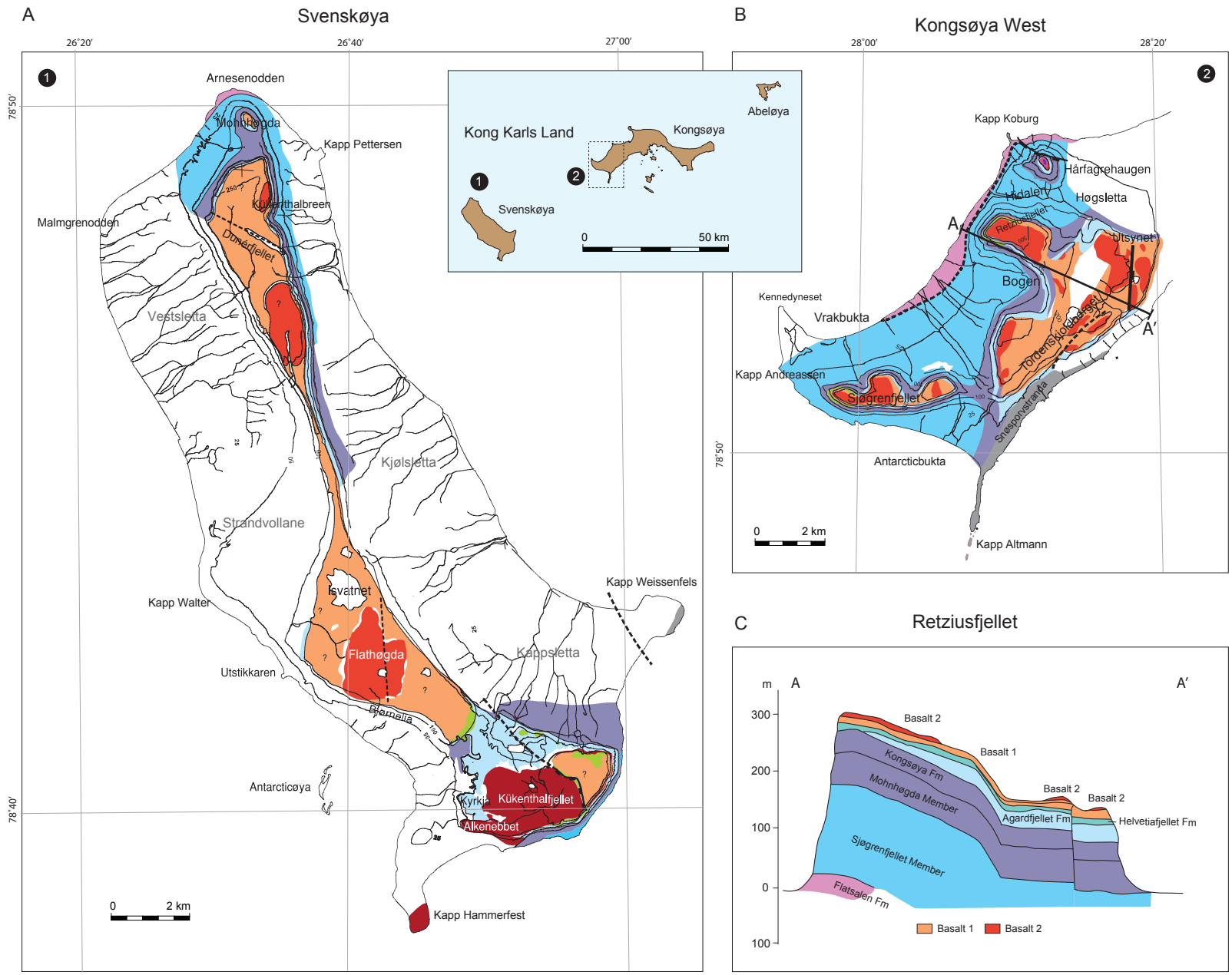

B
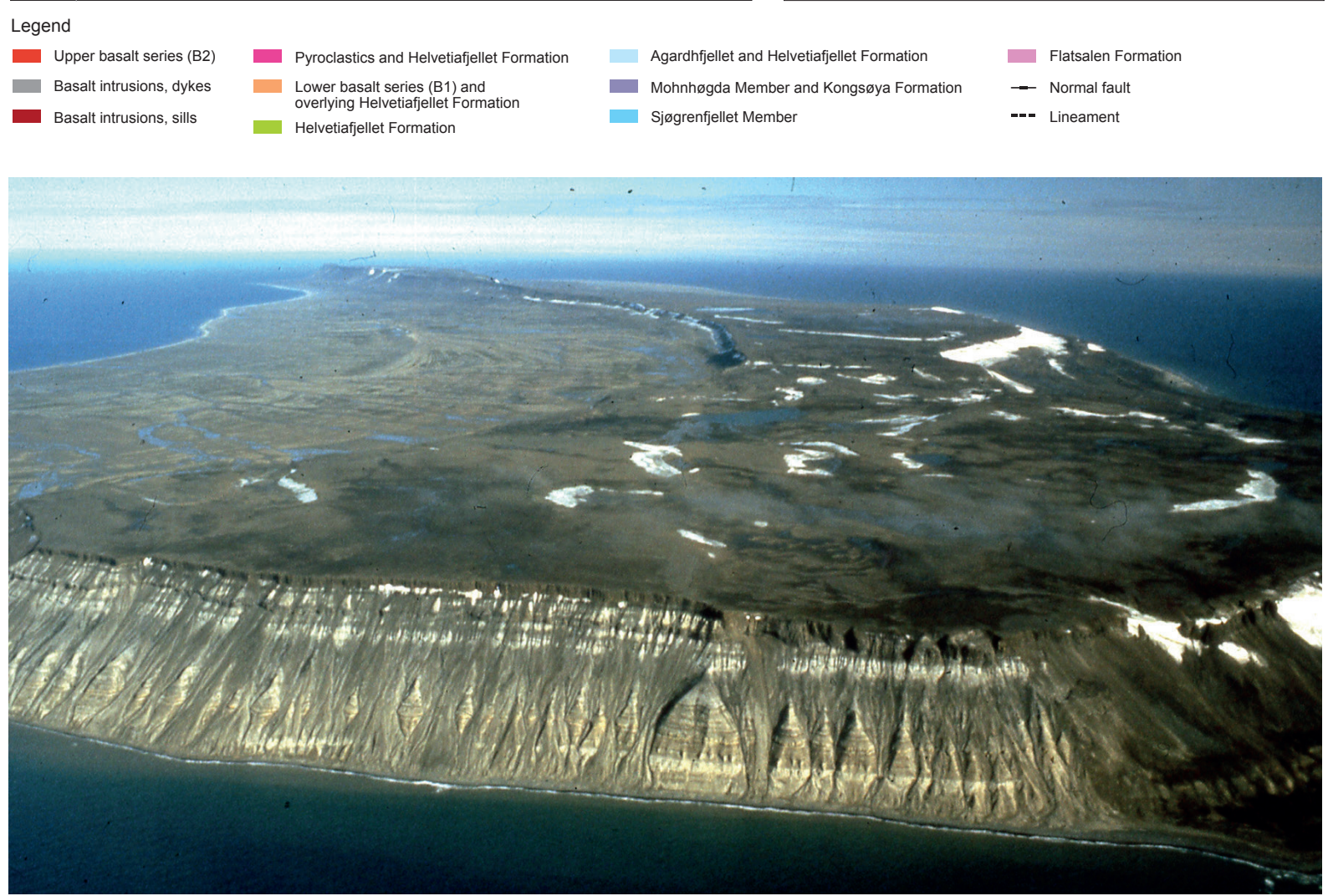

Figure 2. Geological maps. A-Svenskøya (2a), B-Western Kongsøya, C-Simplified profile A-A' across western Kongsøya through Retziusfjellet constructed from the geological map. D - Kükenthalfjellet, Svenskøya, view towards northwest, sill cover/protect the strata (Photo: Tor Gunnar Gloppen). 


\section{Palynostratigraphic records and zonations in the Barents Sea region}

Results from pioneering palyno-stratigraphic studies on the Mesozoic of Svalbard were presented by Smith (1974), Smith et al. (1975, 1976), Bjærke et al. (1976), Bjærke (1977, 1978, 1980a, b), Bjærke \& Dypvik (1977) and Bjærke \& Manum (1977), while the first record of Mesozoic palynomorphs from the Barents Shelf was reported by Bjærke \& Thusu (1976). As petroleum exploration commenced in the western Barents Sea in the early 1980s the increasing need for more stratigraphic data initiated a series of studies aimed at providing a more detailed lithoand biostratigraphic framework for the depositional sequences on Svalbard and on the Barents Shelf.

Research programmes on Svalbard have been carried out by SINTEF Petroleum Research in cooperation with several geological surveys and research organisations in Canada, Denmark, Germany and Russia, and several in-house programmes were conducted by petroleum companies active in the exploration of the Barents Shelf. Most of the information from these studies is still not published (example: Århus, 1988). In addition, palynostratgraphic information on the Mesozoic succession on Svalbard and the Barents Shelf is found in several unpublished MSc. theses (Fiksdal, 1988; Dalseg, 2012; Ask, 2013; Holen, 2014; Landa, 2015; Meltveit, 2015 and others). The history of the palynostratigraphic research on the Triassic succession has been summarized in the comprehensive work by Vigran et al. (2014). A study of the Late Triassic palynology of Hopen has been published by Paterson \& Mangerud (2015), and offshore south of Kong Karls Land by Paterson et al. (2016a).

Following the pioneering works cited above, new palynostratigraphic information from the Jurassic and Cretaceous successions on Svalbard and the Barents Shelf have been published by Smelror (1988a), Wierzbowski \& Århus (1990), Århus (1991), Århus et al. (1990), Grøsfjeld (1992), Smelror \& Below (1992), Smelror et al. (1998), Smelror \& Dypvik (2005), Radmacher et al. (2014a, 2014b), Dalseg et al. (2016a, b), Śliwińska et al. (2016), Smelror \& Larssen (2016) and Grundvåg et al. (2017). In addition to the biostratigraphic publications, taxonomic papers describing new species from the Jurassic and Cretaceous successions of Svalbard and the Barents Shelf have been published by Bjærke (1980a, b), Below (1987a, b), Smelror (1989, 1991), Smelror \& Aarhus (1989), Bailey (1993) and Århus (1992).

Paleoenvironmental, paleoclimatic and paleobiogeographic studies including palynological records from the Mesozoic successions of Svalbard and the Barents Shelf have been conducted by Smelror (1993), Hochuli \& Vigran (2010), Mueller et al. $(2014,2016)$ and Paterson et al. (2016b). A unique event is the phytoplankton bloom induced by the Mjølnir meteorite impact that hit the central Barents Shelf close to the Volgian-Ryazanian boundary (Smelror et al., 2001, 2002; Bremer et al., 2004; Dypvik et al., 2004, 2006; Smelror \& Dypvik, 2006).

Palynostratigraphic zonations covering the whole or parts of the Triassic succession of Svalbard and the Barents Sea have been published by Hochuli et al. (1989), Mangerud \& Rømuld (1991), Mørk et al. (1993, 1999), Vigran et al. (1998, 2014) and Paterson \& Mangerud (2015, 2017). Bjærke (1977) introduced an informal zoning of palynomorphs, Associations (A-F), for the uppermost Triassic (Rhaetian) to Lower Cretaceous succession of Kong Karls Land. Smelror \& Below (1992) proposed a formal dinoflagellate biostratigraphic zonation for the Toarcian to Lower Oxfordian (Jurassic) of the Barents Sea Region, while Dalseg et al. (2016a) introduce informal dinoflagellate cyst zones for the Upper Jurassic-Lower Cretaceous in central Spitsbergen.

In the present study we have applied a composite palynostratigraphic framework based on documented records from the Barents Sea Region and adjacent areas of the Mesozoic Boreal and Subboreal regions. During some periods, the faunas and floras were largely cosmopolitian and comparable throughout the Boreal and Subboreal provinces. In other periods, oceanographic barriers and climatic differences led to the evolution of endemic biotas, which do not allow detailed stratigraphic correlations across and between the biogeographic provinces.

\section{Upper Triassic to Lower Cretaceous lithostratigraphy and sequence stratigra- phy in Kong Karls Land}

The Mesozoic succession on Kong Karls Land consists mainly of Upper Triassic and Lower Jurassic deltaic, estuarine, shoreline and offshore deposits, Middle to Upper Jurassic oxic and anoxic offshore deposits, and Lower Cretaceous condensed offshore deposits, followed by Lower Cretaceous coastal-plain fluvial deposits, capped or intersected by plateau lavas and pyroclastic rocks (Fig. 3).

The close lithological relationships between the deposits on Svalbard, the western Barents Shelf and the nearby Arctic basins have been documented by several synthesis and comparisons studies (Harland, 1973; Kelly, 1988; Worsley, 2008; Johannessen \& Embry, 1989; Nøttvedt et al., 1992; Mørk et al., 1993; Smelror et al., 1998, 2009; Mørk \& Smelror, 2001; Henriksen et al., 2011; Grundvåg et al., 2017). The onshore-offshore link between Svalbard and the Barents Shelf is illustrated by the formal lithostratigraphic nomenclature of groups linking the Upper Palaeozoic and Mesozoic successions of the two areas (Dalmann, 1999). The lithostratigraphic subdivision 


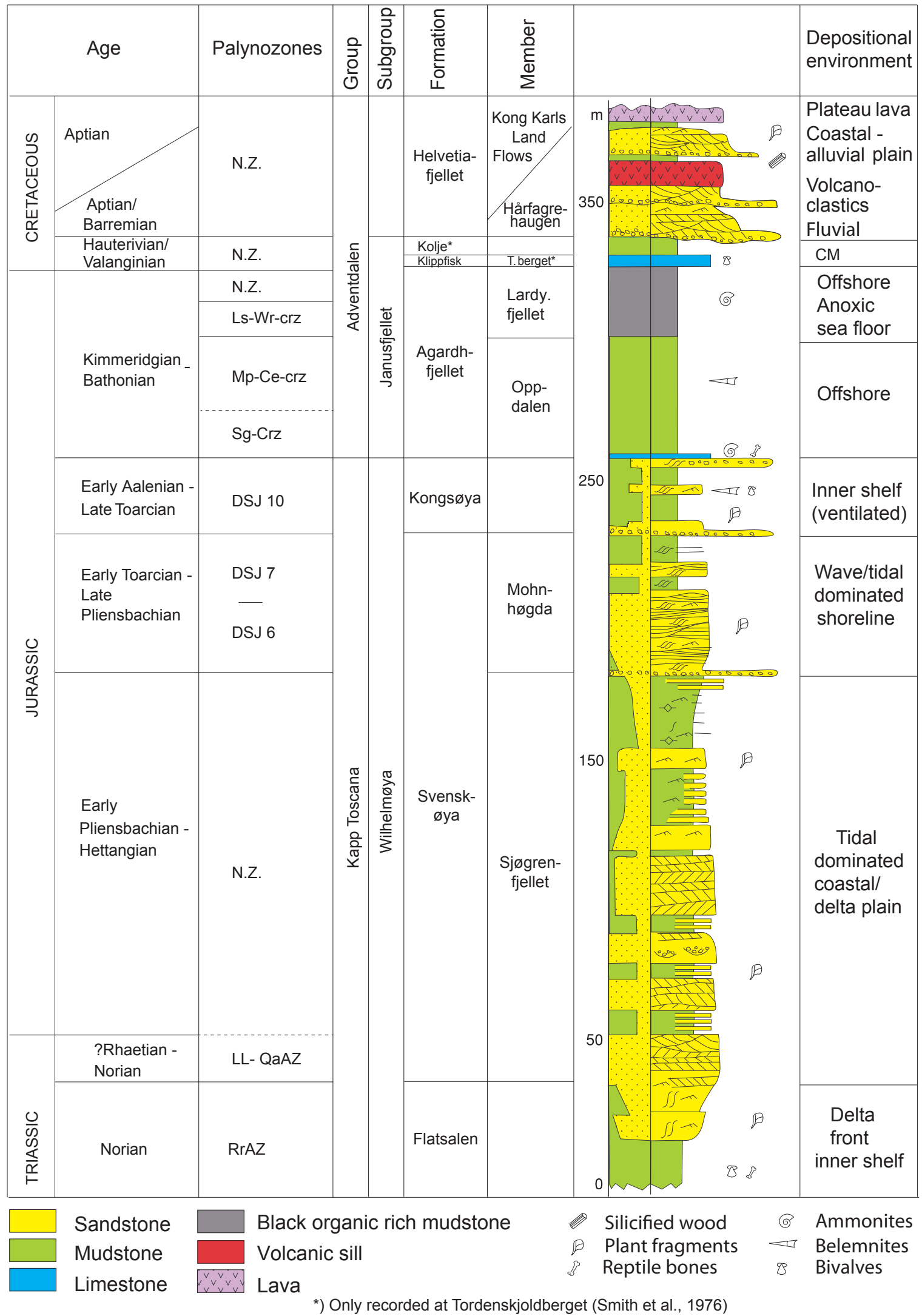

Figure 3. Lithostratigraphy of the Upper Triassic to Lower Cretaceous succession on Kong Karls Land, and palynostratigraphic zones used for age determinations and correlations in the present study. KKLF $=$ Kong Karls Land Flows, Fm $=$ Formation, Mbr $=$ Member, RZaz $=$ Rhaetogonyaulax rhaetica Assemblage Zone (Paterson \& Mangerud, 2015), Ll-QaAZ = Limbosporites lundbladii-Quadraeculina anellaeformis Assemblage Zone (Paterson \& Mangerud, 2015), DSJ6, DSJ7 \& DSJ10 =Dinoflagellate cyst zones in the NW Subboreal Europe (Poulsen \& Riding, 2003), Sg-crz = Sirmiodinium grossii concurrent range-zone (Smelror \& Below, 1992), Mp-Ce-crz = Meiourogonyaulax planoseptata-Chlamydophorella ectotabulata concurrent range-zone (Smelror \& Below, 1992), Ls-Wt-crz = Liesbergia scarburghensisWanaea thysanota concurrent range-zone (Smelror \& Below, 1992), N.Z. = not zoned. 
of the Mesozoic strata on Kong Karls Land used in the present paper follows the formal stratigraphy outlined in the Lithostratigraphic Lexicon of Svalbard (Dallmann, 1999; Mørk et al., 1999), where also the groups, formations and members defined for the western Barents Sea by Worsley et al. (1988) are incorporated.

The lithostratigraphic units included in the present study include the Flatsalen, Svenskøya and Kongsøya formations of the Wilhelmøya Subgroup of the Kapp Toscana Group, and the Agardhfjellet, Klippfisk, Kolje and Helvetiafjellet formations of the Adventdalen Group (Mørk et al., 1999). In addition, Early Cretaceous basalts of the Diabasodden Suite crop out on the Kong Karls Land archipelago (Dallmann, 1999).

The Flatsalen Formation was first defined on Hopen and was later extended to eastern Spitsbergen, Wilhelmøya and Kong Karls Land. The formation is of Norian age and consists dominantly of dark grey silty shale, partly interbedded with, and grading into, siltstone and finegrained sandstone (Larssen et al., 1995; Mørk et al., 1999; Olaussen et al., 2018). The lower part of the formation is not exposed on Kong Karls Land. The base of the formation in Hopen, Wilhelmøya and East Spitsbergen concurs with the lower boundary of the calcareous Slotted Bed (Mørk et al., 1999; Rismyhr et al., in press).

The Flatsalen Formation was deposited in a shallowmarine and near-shore environment (Smith et al., 1975; Mørk et al., 1999). The flooding and transgression in the lower Flatsalen Formation is followed by an equally pronounced regression represented by gradually shallowing and coarsening upward units suggesting coastal and deltaic progradation. According to Olaussen et al. (2018), the Flatsalen Formation on Kong Karls Land is interpreted to represent lower to middle shoreface or delta-front deposits, while the exposures on Hopen suggest deposition in offshore to lower shoreface environments.

The boundary surface between the Flatsalen Formation and the overlying Svenskøya Formation is exposed on Hopen (Lord et al., in press) and on Wilhelmøya, where it is recognised as an erosive surface followed by fluvial and estuarine channels. This surface is not exposed on Kong Karls Land.

The Svenskøya Formation was originally defined on Kong Karls Land by Smith et al. (1976). Here we have followed the revised definition as proposed by Mørk et al. (1999). The Svenskøya is of latest Triassic to Early Jurassic age (Smith, 1974; Smith et al., 1976; Bjærke, 1977; Pčelina, 1980; Vigran et al., 2014; Paterson \& Mangerud, 2015; Paterson et al., 2016a). The formation consists dominantly of sandstones and is divided into the Sjögrenfjellet and Mohnhøgda members. The Sjögrenfjellet Member consists of greenish, fine- to medium-grained sandstone, grading into fine-grained, white sandstone with thin mudstone beds. The overlying Mohnhøgda Member consists of yellow and white, fined-grained sandstone, in some places with carbonate cement (Mørk et al., 1999; Olaussen et al., 2018).

The upper part of the Sjögrenfjellet Member shows facies similarities to the tidal and coastal-plain deposits of the Nordmela Formation in the southwestern Barents Sea (Olaussen et al., 1984; Gjelberg et al., 1987), while the Mohnhøgda Member was deposited along a wave- to tidaldominated shoreline or in a protected bay environment, and is seen as an overall regressive unit. This regressive unit comprises mouth bars and fluvial channels in the upper part (Olaussen et al., 2018). There was a significant change in depositional environment from the protected, tidally-dominated, coastal-plain environment of the Sjøgrenfjellet Member to the more open, wave-influenced basin regime in the Mohnhøgda Member.

At the base, the Mohnhøgda Member consists of a gravel bed formed by wave erosion associated with a ravinement surface. This is a key stratigraphic marker on Kong Karls Land and elsewhere on Svalbard (Nagy \& Berge, 2008; Rismyhr et al., in press).

The Kongsøya Formation was first described on Kongsøya, Kong Karls Land, by Smith et al. (1976). The revised definition used herein follows the one proposed by Larssen et al. (1995) and subsequently formally published by Mørk et al. (1999). This definition corresponds to the description of the Passet Clay Member of the Kongsøya Formation as originally proposed by Smith et al. (1976).

The Kongsøya Formation consists of alternating finegrained muddy sandstones and mudstones with siderite beds and siderite concretions, belemnite conquina beds and minor conglomerates with pebbles of quartz and siderite (Mørk et al., 1999). Incorporated in the formation is the Vrakbukta Bed, a marker bed in the middle of the formation consisting of bioturbated carbonate-cemented siltstones and fine-grained sandstones.

The Kongsøya Formation in Kong Karls Land, with its several units of condensed deposits (i.e., Vrakbukta Bed, Bogen Member) was deposited in a shallow marine, inner shelf setting (Larssen et al., 1995; Mørk et al., 1999). The formation is commonly given a general ToarcianBathonian age (Smith et al., 1976; Bjærke 1977; Løfaldli \& Nagy, 1980; Pčelina 1980; Doyle \& Kelly, 1988; Fiksdal 1988; Smelror, 1988a), but the palynostratigraphic data restrict the age on Kong Karls Land to Late ToarcianEarly Aalenian. While the upper and lower boundary surfaces of the Kongsøya Formation are well defined on Kong Karls Land, the highly condensed nature of the units and also the possible intraformational breaks makes a sequence-stratigraphic approach challenging.

On Kong Karls Land the Agardhfjellet Formation was originally described as the 'Retziusfjellet Shale Member' 
on Kongsøya by Smith et al. (1976) and placed with its lateral equivalents 'Dunéfellet' and 'Nordaustpynten shale members' in the Kongsøya Formation. Mørk et al. (1999) changed the 'Retziusfjellet Shale Member' to the Agardhfjellet Formation, and the vertical 'Dunéfellet' and 'Nordaustpynten shale members' to the Bünsowbukta and Høgsletta members. Due to their lithological similarities to the Spitsbergen strata, Olaussen et al. (2018) suggest to reassign the two members to the Oppdalen and Lardyfiellet members as described from the Agardhfellet Formation in Central Spitsbergen (Dypvik et al., 1991; Mørk et al., 1999).

On Kongsøya, the Oppdalen Member consists of grey to dark-grey mudstones with siderite concretions, while the overlying Lardyfjellet Member comprises black, organic-rich mudstones (Smith et al., 1976; Larssen et al., 1995; Dallmann 1999). The Agardhfjellet Formation was deposited in a marine, inner shelf environment, partly with restricted bottom-water circulation. On Kong Karls Land the age of the Agardhfellet Formation is Bathonian to Kimmeridgian (Smith et al., 1976; Bjærke 1977; Smelror, 1988a; Dallmann 1999; Olaussen et al., 2018). The lower and upper boundaries of the formation are well defined in most of the Kong Karls Land archipelago.

The Klippfisk Formation, first formally described from the Bjarmeland Platform, represents a condensed carbonate unit occurring in platform areas (Smelror et al., 1998). The formation also includes the coeval Tordenskjoldberget Member on Kong Karls Land described as the 'Tordenskjoldberget Limestone Member' by Smith et al. (1976), who also included the overlying $15 \mathrm{~m}$ of shale, now assigned to the Kolje Formation, in their member. Here, we follow the formal definition of the member as described by Smelror et al. (1998). The Tordenskjoldberget Member is of ValanginianHauterivian age (Bjærke, 1977; Verdenius, 1978; Smelror et al. 1998). The base of the formation corresponds to the Base Cretaceous Unconformity (BCU) seen on nearby offshore seismic and recognised in boreholes farther south in the Barents Sea.

The Kolje Formation equivalent consists of dark-brown to grey shale and mudstone, with minor interbeds of limestone and dolomite. The formation was originally defined in the Hammerfest Basin. The $15 \mathrm{~m}$ of shale overlying the Tordenskjoldberget Member on Kongsøya, Kong Karls Land, is included in the Kolje Formation (Smelror et al., 1998, Mørk et al., 1999). On Kongsøya the Kolje Formation equivalent is of Barremian age, and was deposited in open marine environments, partly in areas with oxygen-reduced, bottom water conditions (Løfaldli, 1978; Smelror et al., 1998).

On Kong Karls Land, the Helvetiafiellet Formation consists of the Hårfagrehaugen Member and the Kong Karls Land Flows. The Hårfagrehaugen Member consists of coarse sand, sandstones, with subordinate shale and thin coal seams. Sandstones dominate in the lower part of the Hårfagrehaugen Member, while interbedded mudstones, sandstones and coal are most common in the upper part. Silicified wood fragments are abundant. The member is probably of Barremian age and was mainly deposited in fluvial channels in incised valleys and floodplain/delta-plain environments (Larssen et al., 1995; Mørk et al., 1999; Olaussen et al., 2018).

On Kongsøya, the lower part of the Hårfagrehaugen Member consists of yellow/white sandstones and conglomerates with quartzite pebbles, mudstones and coal fragments (Larssen et al., 1995; Mørk et al., 1999). Apart from the area where the Klippfisk and Kolje formations are preserved, the Helvetia Formation cuts down into the Lardyfjellet Member or older parts of the Agardhfjellet Formation.

On Kongsøya, the lower part of the Hårfagrehaugen Member consists of yellow to white sandstones and conglomerates, with quartzite pebbles, mudstones and coal fragments. There is a sharp boundary to overlying green sandstones with volcanoclastic and quartzitic pebbles, representing the onset of volcanic activity (Olaussen et al., 2018).

The Kong Karls Land Flows comprise two basaltic lava flows and associated pyroclastic rocks preserved within the sediments of Hårfagrehaugen Member. At Kükenthalfjellet on Svenskøya, sills and dykes are found at the same stratigraphic level. The basalts are actually classified as andesites. Limited biostratigraphic control of the interbedded shales and sandstones within the plateau lava has indicated only an Early Cretaceous age. Age determinations of bentonites from the middle part of the Helvetiafjellet Formation on Spitsbergen give an Early Aptian age, with a U/Pb age of $123.3 \pm 0.2 \mathrm{Ma}$ (Corfu et al., 2013). On Spitsbergen, biostratigraphic data give an Early Aptian age for the uppermost part of the formation (Midtkandal et al., 2016).

The lavas on Kong Karls Land and the bentonites in Adventdalen on Spitsbergen are part of the High Arctic Large Igneous Province, which has previously been dated as Barremian to Aptian/?Albian (Campsie et al., 1988; Bailey \& Rasmussen, 1997; Maher, 2001; Tegner et al., 2015).

\section{Palynostratigraphy of the Flatsalen Formation}

The present study includes three samples from a section at Kapp Koburg on Kongsøya (Figs. 4, 5 \& 6). These represent the oldest sediments exposed on Kong Karls Land. The samples contain abundant Deltoidospora spp. and bisaccate pollen (20-60\% of the palynological 


\begin{tabular}{|c|c|c|c|c|c|c|}
\hline \multicolumn{2}{|c|}{ LITHOLOGY } & \multicolumn{2}{|c|}{ STRUCTURES } & \multicolumn{2}{|c|}{ FOSSILS AND P ARTICLES } & \multirow{2}{*}{$\begin{array}{l}\text { VARIOIUS } \\
\mathbb{\text { Faults }}\end{array}$} \\
\hline $\begin{array}{ll}\because & 0 \\
\because & 0\end{array}$ & Conglomerate & 目 & Trough/planar cross stratification & \& & Vertebrates & \\
\hline$\because$ & Sandstone & हो & Tabular/planar cross stratification & $\approx$ & Brachiopods & \\
\hline & Grey shale & $\pi$ & Ripples & $\Delta^{\circ}$ & Lingula & Cu unit \\
\hline & Black shale & 同 & Wave ripples & 6 & Ostracods & \\
\hline \begin{tabular}{|l} 
\\
\end{tabular} & Sandy limestone & $\simeq$ & Wavy bedding & $\triangle$ & Cephalopods, mostly belemnites & \\
\hline קובי & Limestone & $\diamond$ & Lenticular bedding & 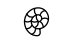 & Ammonoids & \\
\hline & Coal & $=$ & Planar lamination & $\varnothing$ & Plants fragments & \\
\hline 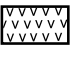 & Basalt/lava & $\infty$ & Hummocky cross stratification & $\gamma$ & Vertical burrows & \\
\hline 0000 & Conglomerate beds & $\approx$ & $\begin{array}{l}\text { Hummocky cross stratification } \\
\text { with mud drapes }\end{array}$ & $\underset{\frac{5}{5}}{4} \mathbb{4}$ & Bioturbation intensity & \\
\hline$\Delta \nabla$ & Cherty & $\infty$ & Concretions & \begin{tabular}{l|l}
$\stackrel{\Xi}{0}$ & $\$$ \\
$\stackrel{0}{\leftrightarrows}$ & 3
\end{tabular} & & \\
\hline$\perp$ & Calcareous & $\ddot{\circ}$ & Erosive surface & & & \\
\hline$>$ & Sideritic & & & & & \\
\hline$\square$ & Coaly, coal lenses or fragments & & & & & \\
\hline$P$ & Pyrite & & & & & \\
\hline
\end{tabular}

Figure 4. Legend to the lithological profiles shown in Figs. 5-10.

assemblages), and common Araucariacidites spp. and Eochasmatosporites magnus (5-20\% of the assemblages). Taxa of biostratigraphic significance include Protodiploxypinus spp., Plaesiodictyon mosellanum and Quadraeculina anellaeformis. Marine taxa include common Veryhachium spp. and rare Cymatiosphaera spp., Micrhystridium spp., Pterospermopsis spp. and Rhaetogonyaulax sp.. The latter species is restricted to the two uppermost samples from the Flatsalen Formation.

The presence of Rhaetogonyaulax sp. and other common marine palynomorphs suggest a correlation to the Rhaetogonyaulax rhaetica Assemblage Zone as defined in the lower Flatsalen Formation on Hopen (Paterson \& Mangerud, 2015). The abundance peaks of Deltoidospora spp. and bisaccate pollen further constrain this correlation. An Early Norian age for this assemblage zone is well constrained by the ammonite records (Korčinskaya, 1980; Smith, 1982; Mørk et al., 1993) and magnetostratigraphy (Lord et al., 2014). The present assemblage from the Flatsalen Formation corresponds to palynological association A described by Bjærke (1977) from a shore cliff northeast of Harfagrehaugen (i.e., close to the same section at Kapp Koburg as the present material comes from). Comparable assemblages are earlier recorded from Unit D of the Wilhelmøya Formation in Sassendalen (Bjærke \& Dypvik, 1977).

The analysed samples from Flatsalen Formation on Kongsøya further correlate to the Rhaetogonyaulax spp.
Composite Assemblage Zone as defined by Vigran et al. (2014), dated as ?Late Carnian-Early Norian, and partly to assemblage C-2 in the zonation of Hochuli et al. (1989). According to Vigran et al. (2014) the Rhaetogonyaulax spp. Composite Assemblage Zone is recorded from the Isforden Member of the De Geerdalen Formation at Festningen in western Spitsbergen. It is also recognised in the lowermost Flatsalen Formation on Wilhelmøya and Hopen. The Rhaetogonyaulax spp. Composite Assemblage Zone is further recorded in shallow stratigraphic cores on Sentralbanken and in several exploration wells in the Barents Sea (i.e., the Snadd and lowermost Fruholmen formations) (Vigran et al., 2014).

\section{Palynostratigraphy of the Svenskøya Formation}

The present study includes material from sections at Hårfagrehaugen, Mohnhøgda, Passet and Retziusfjellet covering the Sjøgrenfjellet Member and from sections at Kükenhalfjellet, Hårfagrehaugen, Moenhøgda and Retziusfjellet covering the Moenhøgde Member (Olaussen et al., 2018).

The most comprehensive analysed section of the Sjøgrenfjellet Member is one at Hårfagrehaugen (Figs. 7 \& 8). The oldest deposits of this profile contain 


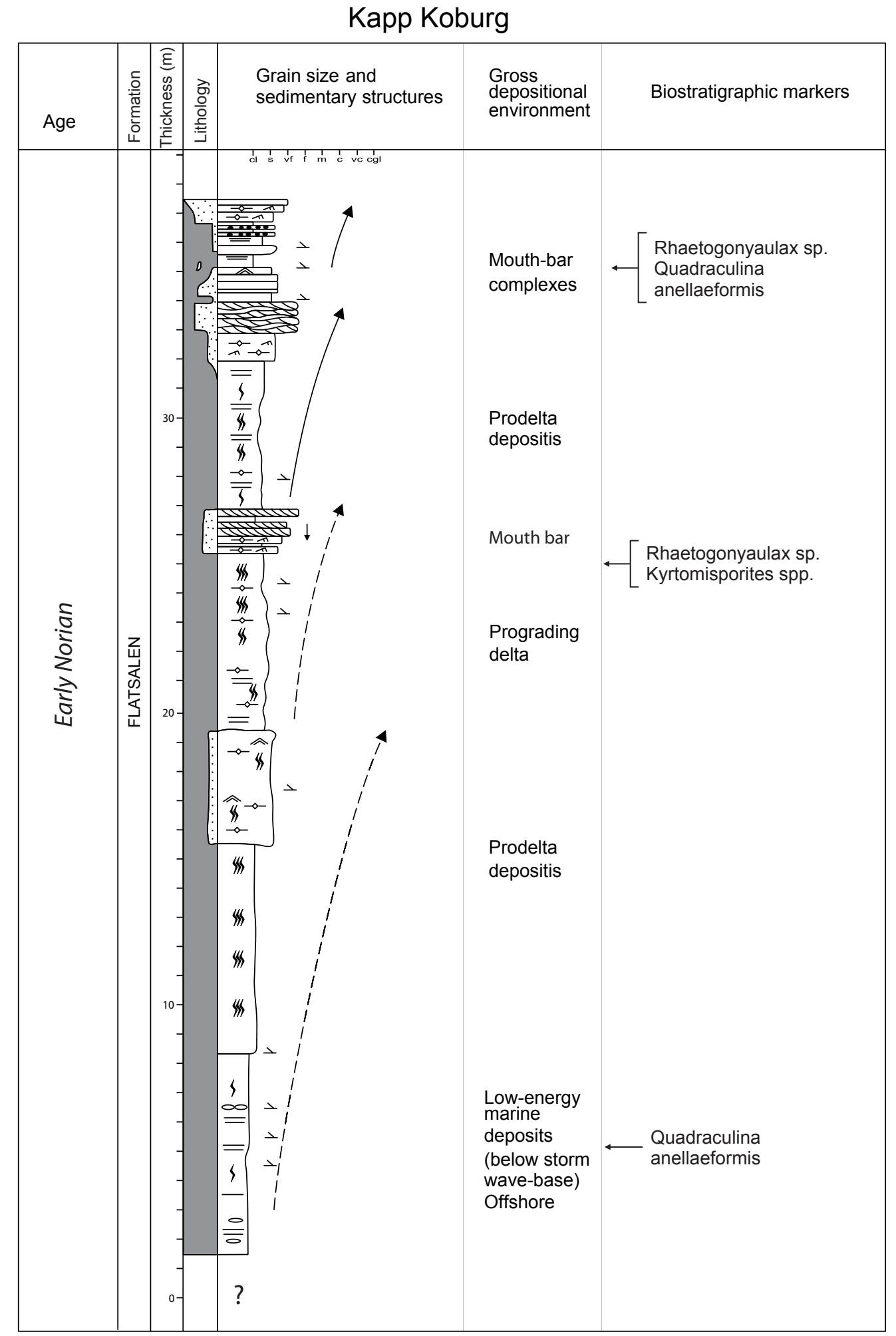

Figure 5. Lithological profile of the Flatsalen Formation at Kapp Koburg on Kongsøya, with positions of the key palynostratigraphic markers.

characteristic Late Triassic terrestrial palynomorphs including Apicilatisporites paravispinosus, Aratrisporites spp., Camarozonosporites spp., Granoperculatisporis rudis, Kyrtomisporis spp., Limbosporites lundbladii, Ovalipollis pseudoalatus and Quadraeculina anellaeformis. The only marine palynomorphs recorded in this part of the formation are Tasmanites sp. and a few spheromorphs.
The appearance of Limbosporites lundbladii and Quadraeculina anellaeformis in the lowermost Sjøgrenfjellet Member suggests that this unit can be correlated with the Limbosporites lundbladii Quadraeculina anellaeformis Assemblage Zone of Norian-?Rhaetian age as defined in the lower Svenskøya Formation on Hopen by Paterson \& Mangerud (2015). 


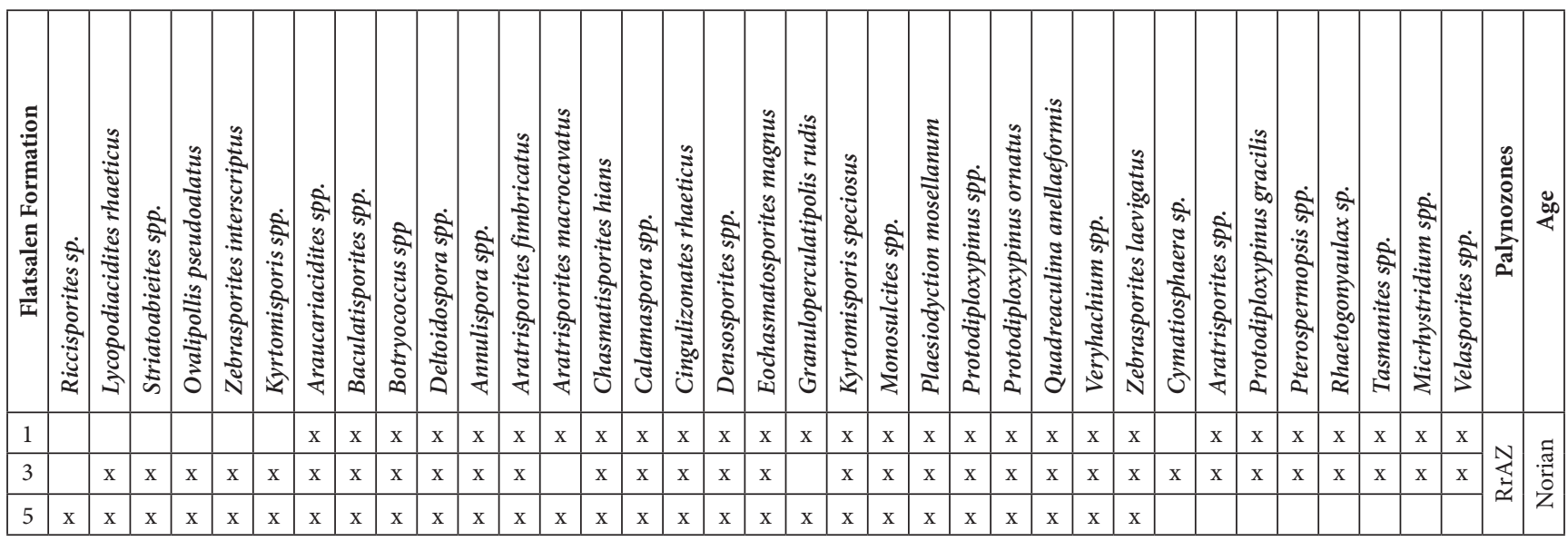

Figure 6. Range chart of palynomorphs recovered from the Flatsalen Formation at Kapp Koburg, Kongsøya. RrAZ = Rhaetogonyaulax rhaetica Assemblage Zone.

The absence of dinoflagellate cysts and acritarchs and the presence of Kyrtomisporis spp. and Protodiploxypinus spp. support this correlation.

The palyno-assemblage from the lower Sjøgrenfjellet Member on Kongsøya can further be correlated with Assemblage B-1 of Hochuli et al. (1989) and upper part of the Limbosporites lundbladii Composite Assemblage Zone as defined by Vigran et al. (2014). Palynofloras that can be correlated to the Limbosporites lundbladii Composite Assemblage Zone are recognised in the Tverrbekken Member (lowermost Knorringfjellet Formation) at Festningen in western Spitsbergen (Vigran et al.,2014) and at Sassendalen in central Spitsbergen (Bjærke \& Dypvik, 1977). According to Vigran et al. (2014) the Limbosporites lundbladii Composite Assemblage Zone is also recorded in shallow stratigraphic cores on Sentralbanken and in the Fruholmen Formation in exploration wells in the western Barents Sea.

In the middle part of the Sjøgrenfjellet Member at Hårfagrehaugen (Fig. 8), the oldest appearance of Cerebropollenites thiergartii suggests a Hettangian age at this level, as the first appearance of this species appears to mark the base of the Jurassic in the Northwest European Subprovince (Subboreal Province) (von Hillebrandt et al., 2007; Cirilli, 2010). However, there are apparent biogeographic differences between the NW European Subboral and the Boreal palynofloras of the present Arctic domain, and diachronic ranges may well occur (Hochuli et al., 1989; Hochuli \& Vigran, 2010; Paterson \& Mangerud, 2015).

Both Limbosporites lundbladii and Quadraeculina anellaeformis are found above this stratigraphic level, while Camarozonosporites spp., Kyrtomisporis spp., Lunatisporites rhaeticus and Protodiploxypinus spp. are missing (i.e., they are not found above the lower part of the Sjøgrenfjellet Member). Ricciisporites tuberculatus and
Cinguizonates rhaeticus have their youngest (uppermost) occurrences in the middle part of the Sjøgrenfjellet Member in the Hårfagrehaugen profile concurrent with the oldest appearance of $C$. thiergratii (Fig. 8).

Palynological assemblages from the upper part of the Siøgrenfjellet Member have been recovered at Hårfagrehaugen, Retziusfjellet, Passet and Moenhøgda (Larssen et al., 1995; Olaussen et al., 2018). Bisaccat pollen and the freshwater algae Botryococcus are abundant to dominant in most of the analysed samples. Cerebropollenites thiergartii is present in all analysed samples from the upper Sjøgrenfjellet Member (Fig. 8). The lack of good biostratigraphic markers makes it difficult to provide a reliable dating of the upper Sjøgrenfjellet Member and a general Hettangian to Early Pliensbachian age is inferred based on the overall composition of the palynological assemblages.

Samples covering the Moenhøgda Member come from sections at Kükenhalfjellet, Hårfagrehaugen, Moenhøgda and Retziusfjellet (Figs. 9 \& 10). The well preserved palynological assemblages are dominated by biasaccat pollen and miospores, but also contain sporadic occurrences of marine species such as the acritarchs Veryhachium spp., Micrhystridum spp. and Caddasphaera halosa. Some foraminifera linings and dinoflagellate cysts have also been recovered.

Species of stratigraphic importance include the Mancodinium semitabulatum, Nannoceratopis gracilis and Phallocysta spp.(Fig.9). The incoming of M. semitabulatum in the lower part of the Moenshøgda Member suggest a correlation to the Late Pliensbachian DSJ6 dinoflagellate cyst zone in the Subboral NW Europe as defined by Poulsen \& Riding (2003), corresponding to the Luehndea spinosa Zone, Subzone a, in the British Jurassic (Riding \& Thomas, 1992). The oldest appearances of Luehndea spinosa and Nannoceratopsis gracilis somewhat higher 


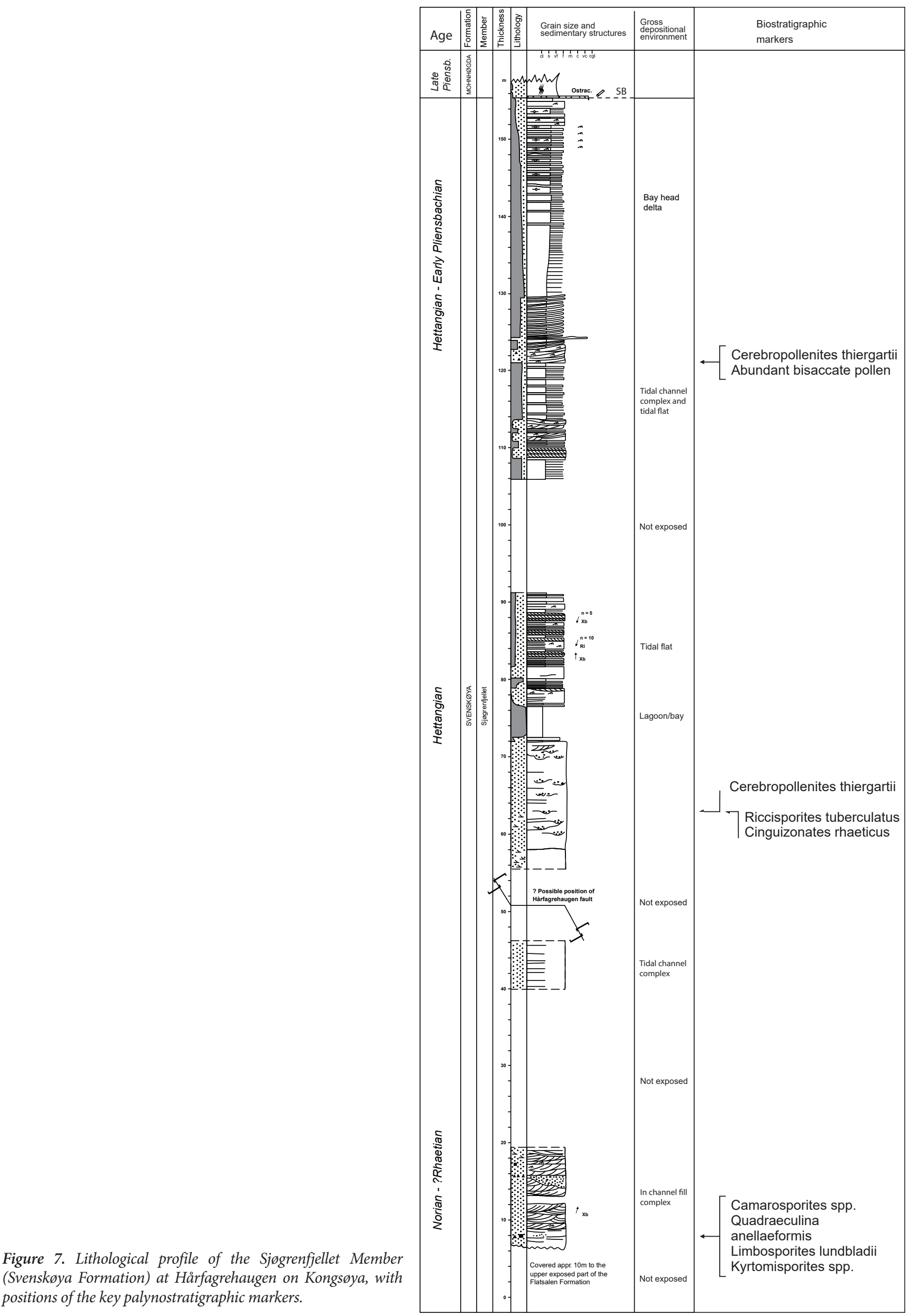




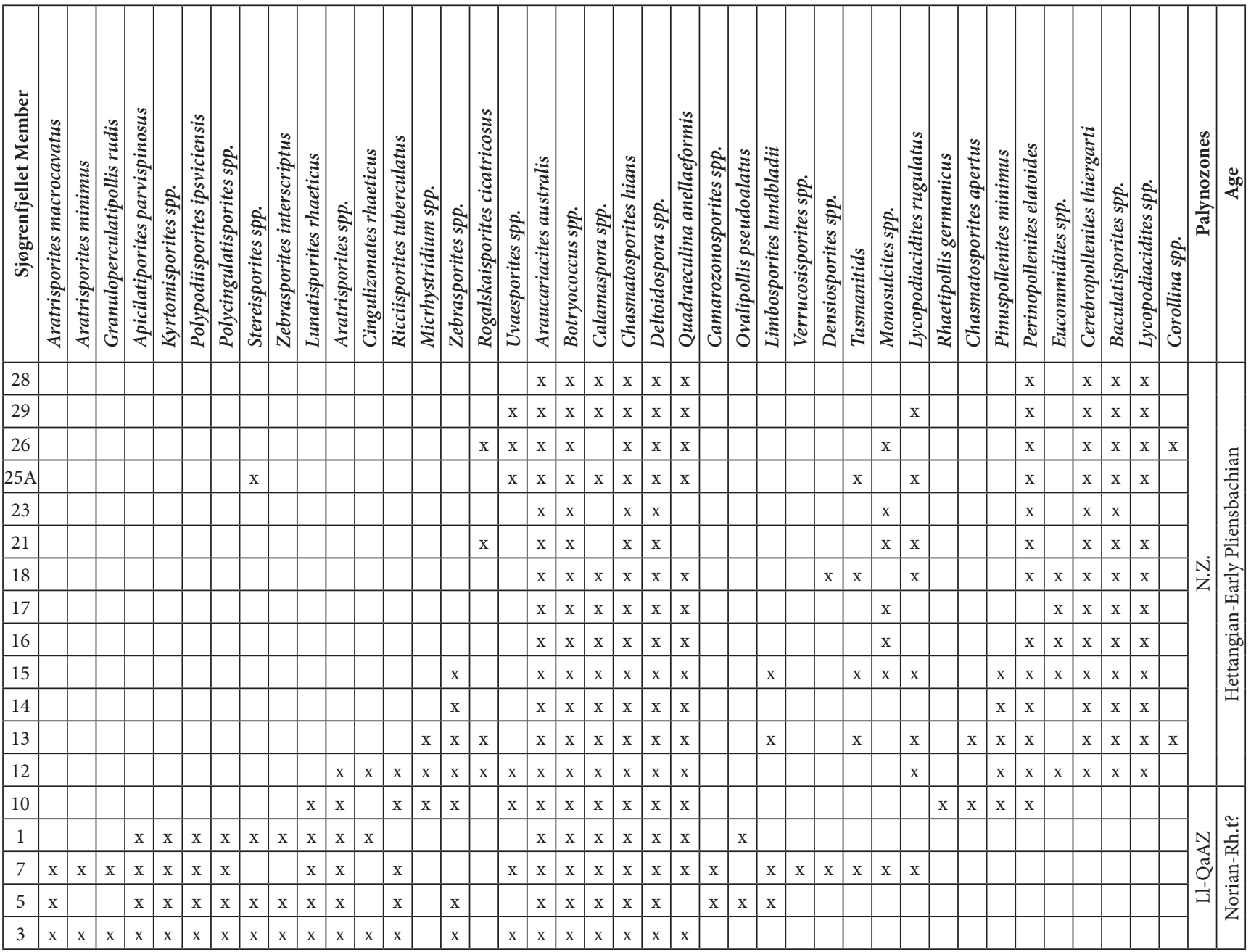

Figure 8. Range chart of palynomorphs recovered from the Sjøgrenfjellet Member (Svenskøya Formation) at Hårfagrehaugen, Kongsøya. Ll-QaAZ $=$ Limbosporites lundbladii-Quadraeculina anellaeformis Assemblage Zone, N.Z. = not zoned.

up in the member support this correlation, and further suggest that the upper part is not younger than Early Toarcian, corresponding to the DSJ7 zone of Poulsen \& Riding (2003) and the Luehndea spinosa Zone, Subzone b, in Britain (Riding \& Thomas, 1992).

During the Late Pliensbachian to Early Toarcian time of global sea-level rise, the dinoflagellate cyst floras appear to have been relatively cosmopolitian, although there are distinct regional differences in the species diversity (Poulsen \& Riding, 2003). Consequently, the age correlation to the macrofossil-calibrated Upper Pliensbachian-Lower Toarcian strata in NW Europe is regarded as fairly reliable.

\section{Possible depositional breaks at the base of, and within, the Svenskoya Formation}

The present study documents a Norian to Early Toarcian age for the Svenskøya Formation on Kong Karls Land, where the lower Sjøgrenfjellet Member is dated as Norian to Early Pliensbachian and the overlying Mohnhøgda Member as Late Pliesbachian to Early Toarcian. In their study of the Upper Triassic to Lower Jurassic deposits in Spitsbergen, Dypvik et al. (1985) found that the Wilhelmøya Subgroup is punctuated by several hiatuses. In their stratigraphic correlation scheme they show a stratigraphic break between the Flatsalen Formation and the overlying Svenskøya Formation on Kong Karls Land. This break spans the Late Norian and Rhaetian time interval. A somewhat comparable disconformity between the Flatsalen and Svenskøya formations on Hopen was suggested by Paterson \& Mangerud (2015), although they placed the break within the Norian.

The boundary between the Flatsalen Formation and the Svenskøya Formation is not exposed on Kong Karls Land, and the present palynostratigraphic record gives no firm evidence of a major break between the formations (Fig. 7). There is change in sedimentary facies from shallow-marine and near-shore shales, siltstones and sandstones of the Flatsalen Formation to the fine-grained tidal-flat, tidal-channel and coastal-plain sandstones of 


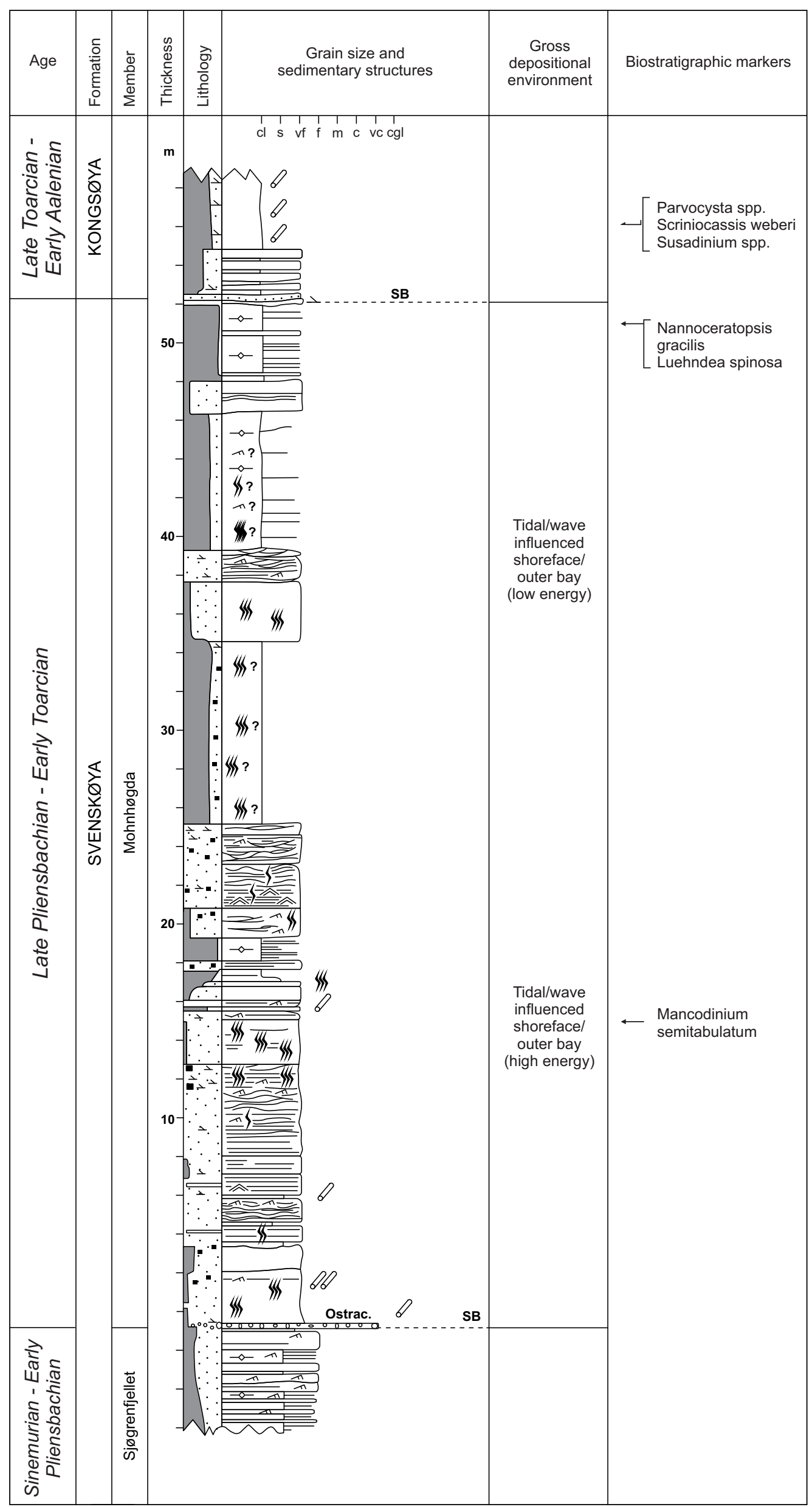

Figure 9. Lithological profile of the Moenhøgda Member (Svenskøya Formation) and the Kongsøya Formation at Hårfagrehaugen on Kongsøya, with positions of the key palynostratigraphic markers. 


\begin{tabular}{|c|c|c|c|c|c|c|}
\hline 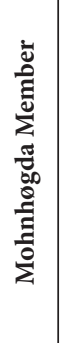 & 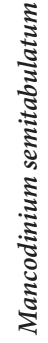 & 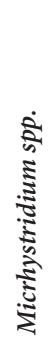 & 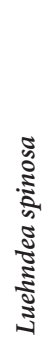 & 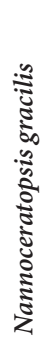 & 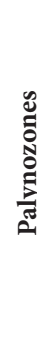 & 范 \\
\hline 5 & & $\mathrm{x}$ & & $\mathrm{x}$ & \multirow{2}{*}{$\widehat{\widehat{n}}$} & \multirow{2}{*}{$\stackrel{\ominus}{\stackrel{0}{\varphi}}$} \\
\hline 4 & & $\mathrm{x}$ & $\mathrm{x}$ & $\mathrm{x}$ & & \\
\hline 3 & & $\mathrm{x}$ & & & \multirow{3}{*}{$\tilde{\omega}$} & \multirow{3}{*}{ 寻 } \\
\hline 2 & $\mathrm{x}$ & & & & & \\
\hline 1 & $\mathrm{x}$ & & & & & \\
\hline
\end{tabular}

Figure 10. Range chart of palynomorphs recovered from the Moenhøgda Member (Svenskøya Formation) at Hårfagrehaugen, Kongsøya. DSJ6 \& DSJ7 = Dinoflagellate cyst zones in the NW Subboreal Europe.

the overlying Sjögrenfjellet Member of the Svenskøya Formation.

On Hopen and Wilhelmøya there is a clear, abrupt change in depositional environment, where offshore to lower shoreface or distal delta-front deposits of the Flatsalen Formation are cut by fluvial or estuarine channels of the Svenskøya Formation. Here, possibly the lower part of the Svenskøya Formation represents an incised valley infill. The boundary between the Flatsalen Formation and the Svenskøya Formation corresponds to the boundary between the Fruholmen and Tubaien formations in the southwestern Barents Sea (Gjelberg et al., 1987).

A pronounced disconformity may be present between the lower and middle-upper parts of the Sjøgrenfjellet Member. In the Hårfagrehaugen profile, Larssen et al. (1995) suggested the presence of a possible fault between the lower part of the member, herein dated as Norian?Rhaetian, and the middle-upper part dated as Hettangian to Early Pliensbachian. The lack of age-diagnostic biostratigraphic markers, however, makes it difficult to estimate the age and duration of any hiatus spanning the Triassic-Jurassic boundary with any accuracy on Kong Karls Land.

\section{Palynostratigraphy of the Kongsøya Formation}

Palynological samples from the Kongsøya Formation were collected from sections at Kükenhalfjellet, Hårfagrehaugen, Moenhøgda, Retziusfjellet and Sørstranda (Larssen et al., 1995; Olaussen et al., 2018). The abundance and number of species of marine microplankton show a marked increase in the Kongsøya
Formation compared with the underlying Svenskøya Formation. The samples were analysed primarily for marine microplankton, which provide the mean for the age determination of the formation.

The Kongsøya Formation contains dinoflagellate cyst assemblages typified by Parvocysta spp., Phallocysta eumekes, Susadinium scrofoides, Eyachia prisca, Scriniocassis weberi and common to abundant Nannoceratopsis gracilis (Figs. 11 \& 12). Similar assemblages have previously been recorded at several places in the Svalbard Archipelago, in the Barents Sea and elsewhere in the NW European Subboreal province (Bjærke, 1980b; Woollam \& Riding, 1983; Riding, 1984; Below, 1987a, b; Fiksdal, 1988; Smelror, 1988a, b; Prauss, 1989; Poulsen, 1992, 1996; Riding \& Thomas, 1992; Smelror \& Below, 1992; Poulsen \& Riding, 2003).

Palynomorphs from the Kongsøya Formation (sensu Dallmann, 1999) at Hårfagrehaugen on Kongsøya have earlier been recorded by Bjærke (1977), Fiksdal (1988) and Smelror (1988a). No age-diagnostic species were reported by Bjærke (1977). Løfaldli \& Nagy (1980), who studied the foraminiferal stratigraphy of the Jurassic deposits on Kongsøya, found an assemblage dominated by Ammodiscus asper. They postulated, with some question marks, a general Late Pliensbachian-Toarcian age for their Ammodiscus asper Assemblage covering the upper part of the Kongsøya Formation (i.e., the upper Passet Member in Løfaldli \& Nagy, 1980). Doyle \& Kelly (1988) described a fauna of small belemnites from the Kongsøya Formation (Passet Member sensu Smith et al., 1976). The recovery of the genera Lenobelus and Paramegateuthis supports a Toarcian-Aalenian age for the formation.

The samples analysed for foraminifera by Løfaldli \& Nagy (1980) were also analysed for palynomorphs by Fiksdal (1988) and Smelror (1988a). Fiksdal (1988) and Smelror (1988a) reported relatively abundant and diverse assemblages of pollen, spores and marine palynomorphs in the Kongsøya Formation (listed as the Passet Member of the Wilhelmøya Formation by Fiksdal op. cit. and Smelror op. cit.). Characteristic terrestrial taxa include Callialasporites spp., Cerebropollenites thiergratii, Cerebropollenties macroverrucosus, Chasmatosporites hians, Chasmatosporites major, Lycosporidiumsporites semimuris, Todisporites spp. and Trachysporites spp (Fiksdal, 1988). Age-diagnostic dinoflagellate cysts found in the formation include species of the Parvocysta-suite of Riding (1984), Susadinium scrofoides, Phallocysta eumekes, Scriniocassis weberi and common Nannoceratopsis spp.

The co-occurrence of Phallocysta eumekes and Susadinium scrofoides in the Kongsøya Formation allows a correlation to the DSJ10 Zone as defined by Poulsen \& Riding (2003) and the Nannoceratopsis gracilis Interval Biozone, Subbiozones b and c, as defined by Riding \& Thomas (1992). The age of these dinoflagellate cyst zones is Late Toarcian to Early Aalenian. 


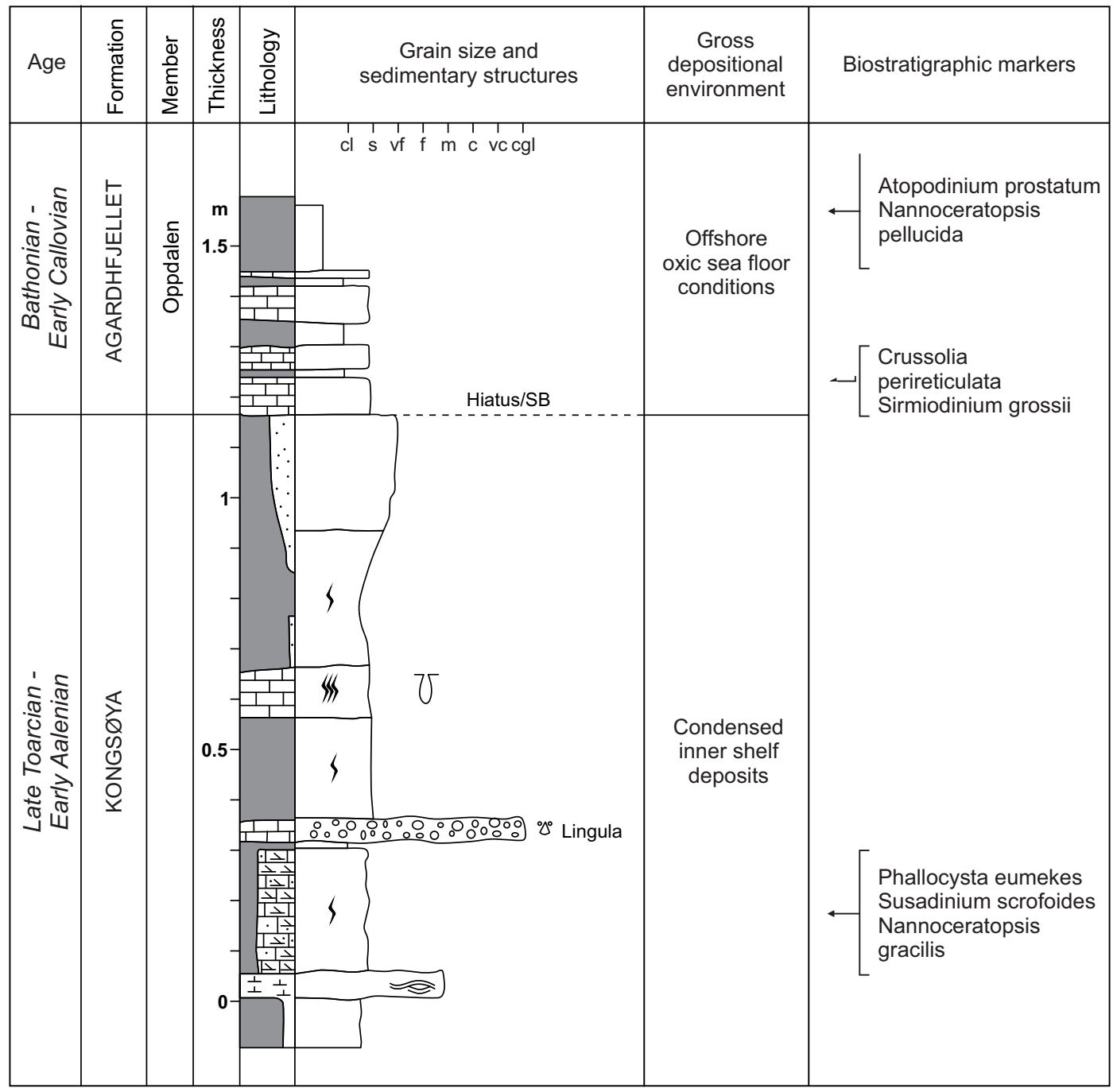

Figure 11. Lithological profile of the upper Kongsøya Formation and lowermost Agardhfjellet Formation at Sørstranda on Kongsøya, with positions of the key palynostratigraphic markers.

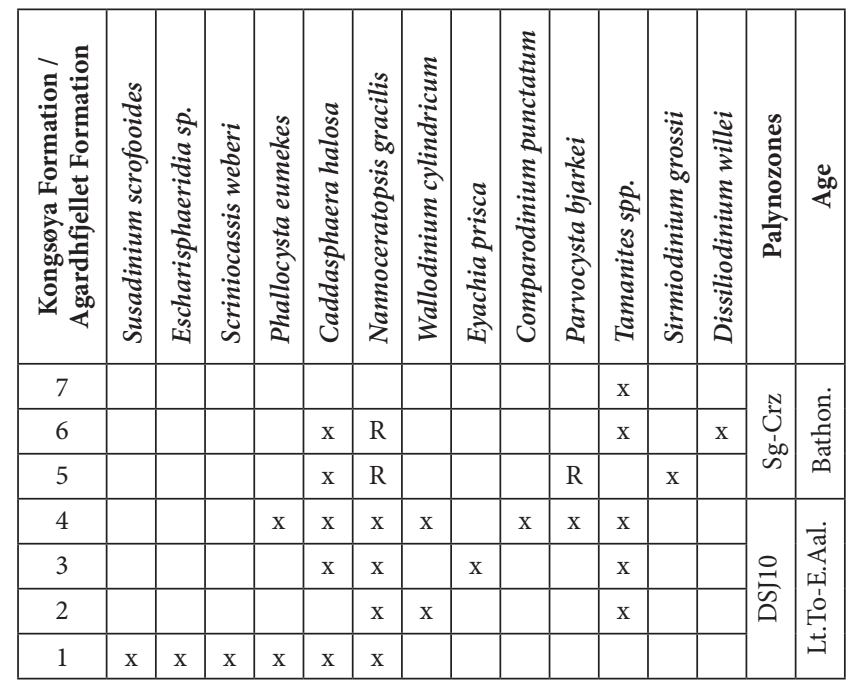

Figure 12. Range chart of palynomorphs in the upper Kongsøya Formation and lowermost Agardhfjellet Formation at Sørstranda, Kongsøya. DSJ10 = Dinoflagellate cyst zone in the NW Subboreal Europe, $\mathrm{Sg}$-crz $=$ Sirmiodinium grossii concurrent range zone, $R=$ reworked.

\section{Age and correlations of the Brentskard- haugen Bed and the boundary between the Wilhelmøya and Janusfiellet subgroups}

The Brentskardhaugen Bed is a distinct stratigraphic marker composed of conglomerates and calcareous sandstones with polymict pebbles and gravels, phosphate nodules with fossils, and ankerite/siderite intercalations (Parker, 1967; Bäckström \& Nagy, 1985; Mørk et al., 1999). The unit has been given a ?Bajocain-Bathonian age. However, this age is not confirmed and the stratigraphic affiliation of the unit is disputed. Different workers have assigned the Brentskaardhaugen Bed to either the Wilhelmøya Subgroup (Kapp Toscana Group) or the overlying Janusfellet Subgroup (Adventdalen Group) (Dallmann, 1999).

At several locations in southern and western Spitsbergen, one or several similar phosphatic conglomerates and 
possible hiatuses occur within the upper part of the Wilhemøya Subgroup (Worsley, 1973; Pčelina, 1980; Mørk et al., 1982; Maher, 1989; Krajewski, 1992). However, no age-diagnostic fossils are documented from these beds, and the ages of these conglomerates and of any associated hiatuses at these locations are not well constrained (Mørk et al., 1999).

On Wilhelmøya (at Tumlingodden), a thin conglomerate forms the boundary between sandstones of the Kongsøya Formation and overlying dark shales of the Agardhfjellet Formation. The Kongsøya Formation contains several conglomeratic horizons, as well as common coal fragments and fossil logs. The sand of the Kongsøya Formation contains rich microfloras, with common marine palynomorphs (Phallocysta eumekes, Cymatiosphaera spp., Nannoceratopsis gracilis, Micrhystridium spp. Ovalicysta hiata, Tasmanites sp.) (Smelror, pers. obs.). The presence of Phallocysta eumekes and Ovalicysta hiata support a correlation to the latest Toarcian-earliest Aalenian DSJ10 dinoflagellate cyst zone (Poulsen \& Riding, 2003).

The lowermost shale of the overlying Agardhfjellet Formation contains common to abundant dinoflagellate cysts, including Chalamydophorella ectotabulata, Ctenidodinium continuum, Crussolia perireticulata, Pareodinia barentsensis, Nannoceratopsis pellucida and Sirmiodinium grossii (Smelror, pers. obs.). The assemblage falls within the Sirmiodinium grossii concurrent rangezone of Late Bathonian-earliest Callovian age (Smelror \& Below, 1992) and correlates with similar assemblages recognised within the lower part of the Agardhfjellet Formation on Kongsøya and Spitsbergen. According to Riding \& Thomas (1992) S. grossii first appears in the Discus ammonite zone in the British Jurassic. In East Greenland the oldest appearance of S. grossii correlates to the Late Bathonian Calyx ammonite zone (Smelror 1988b).

On Kong Karls Land, a conglomerate bed with carbonate nodules containing numerous fossils is found near the top of the Kongsøya Formation (Fig. 11). Above this bed lie sandy limestone, calcite-cemented sandstone, sideritic layers and interfingering claystone. Marine palynomorphs recovered from these sediments give a Late Toarcian-Early Aalenian age, comparable to the underlying Kongsøya Formation deposits. The present observations from Kongsøya place the conglomerate bed on Kong Karls Land as an integral part of the Wilhelmøya Subgroup.

Lateral equivalents of Late Toarcian-Early Aalenian age are found southwards on the shelf in the Hammerfest and Nordkapp basins (Gjelberg et al., 1987; Bugge et al., 2002).

Several authors have interpreted the Brentskardhaugen Bed as a transgressive basal conglomerate initiating the deposition of the Agardhfjellet Formation and have incorporated the bed in the Adventdalen Group (Birkenmajer, 1972; Birkenmajer et al., 1982; Bäckström \& Nagy, 1985; Dypvik et al., 1985, 1991). In central Spitsbergen, the Brentskardhauen Bed is directly followed by the Marhøgda Bed, a unit of limestone with ooids and glauconite containing Late Bathonian fossils (Kopik \& Wierzbowski; 1988). Based on the phosphatic oolites found in the Marhøgda Bed several workers have argued that the Marhøgda Bed is genetically associated with the Brentskardhaugen Bed (Pčelina, 1980; Kopik \& Wierzbowski, 1988; Krajewski, 1992).

Bäckström \& Nagy (1985) found that both the lower and the upper boundaries of the Marhøgda Bed are transitional. In core 7230/05-U-02 drilled in the Nordkapp Basin, the boundary between the Bathonian sandstones of the Kapp Toscana Group (Stø Formation) and the overlying shale of the Adventdalen Group (Fuglen Formation) is marked by a thin pyrite-cemented bed (Bugge et al., 2002). An intraformational conglomerate interpreted as a lateral equivalent to the Brentskardhaugen Bed is present in the middle part of the Stø Formation in this core. In the Nordkapp Basin, there is possibly a hiatus between the Late Toarcian-Early Aalenian phosphorite conglomerate and the overlying fine-grained sandstones of Bajocian age (Smelror, 1991; Bugge et al., 2002). Time-equivalent Bajocian strata, as well as Lower Bathonian deposits, have not been confirmed on Svalbard.

\section{Palynostratigraphy of the Agardhfiellet Formation}

The present palynological study includes material from sections at Kükenhalfjellet (Figs. 13 \& 14), Sørstranda and Tordenskioldberget sampled by Larssen et al. (1995) and previous records from Hårfagrehaugen published by Smelror (1988a). In addition to the palynostratigraphic records, biostratigraphic data published Løfaldli \& Nagy (1980), Rawson (1982) and Doyle \& Kelly (1988) are used for age assessment of the Agardhfjellet Formation.

The dinoflagellate cyst assemblages recovered from the Oppdalen Member (lower part of the Agardhfjellet Formation) are characterised by rare to abundant Sirmiodinium grossii, rare to abundant Heslertonia teichophera, and the presence of Atopodinium prostatum, Chlamydophorella ectotabulata, Ctenodinium continuum, Ctenodinium ornatum, Nannoceratopsis pellucida, Pareodinia barentsensis and Senoniasphaera cf. jurassica (Fig. 14). The assemblages correlate with the Late Bathonian-earliest Callovian Sirmiodinium grossii concurrent range-zone as defined by Smelror \& Below (1992). At some locations the lowermost deposits of the Oppdalen Member contain reworked Late ToarcianAalenian dinoflagellate cysts probably originating from the underlying Kongsøya Formation (Fig. 12). 


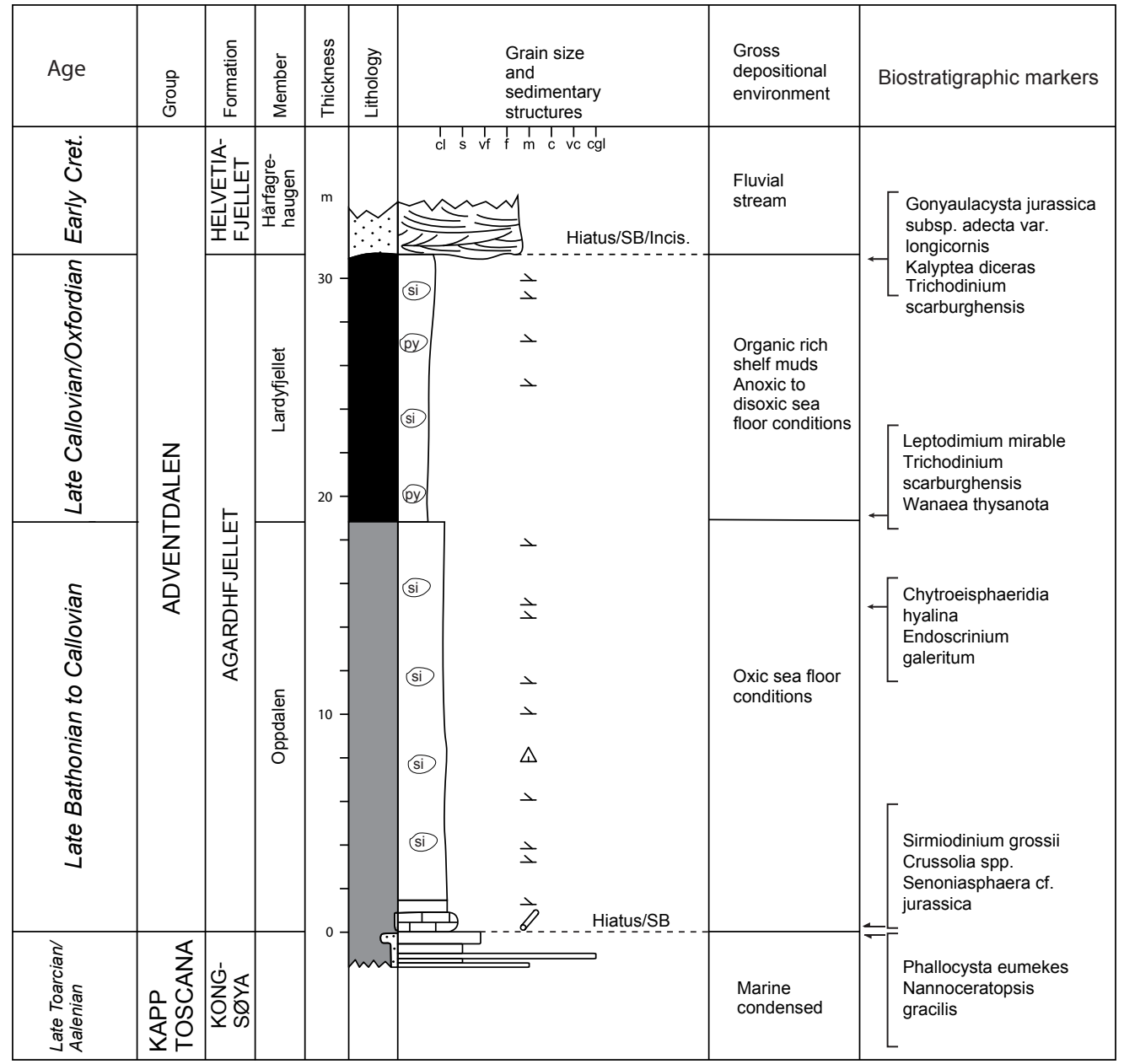

Figure 13. Lithological profile of the Agardhfjellet Formation at Kükenthalfjellet on Kongsøya, with positions of the key palynostratigraphic markers.

The records of the ammonite faunas with Arcticoceras cf. kochi, A. bluethgeni and A. harlandi from the lowermost part of the Oppdalen Member (previously the Bünsowbukta Member of Løfaldli \& Nagy (1980) and Rawson (1982)) suggest a correlation to the Boreal Bathonian Arcticoceras ishmae zone (Kelly et al., 2015). Consequently, the lower boundary of the Sirmiodinium grossii concurrent rangezone of Smelror \& Below (1992) is concurrent with this ammonite zone, and the older part of this dinoflagellate cyst zone is revised to cover the entire Bathonian, not only the Late Bathonian as originally proposed.

The lower boundary of the overlying Early-Middle Callovian Meiourogonyaulax planoseptata Chlamydophorella ectotabulata concurrent range-zone of Smelror \& Below (1992) is defined by the earliest incoming of Meiourogonyaulax planoseptata, and the upper boundary of this zone is defined by the earliest appearance of Trichodinium scarburghensis and/or Wanaea thysonata. Characteristic species recovered from this zone in the Kongsøya Formation include Chytrosphaeridia cerastes, Chytrosphaeridia hyalia, Endoscrinium galeritum, Rhyncodinium cladophora, Meiourogonyaulax spp. and representatives of the
Paragonyaulacysta-Lacrymodinium-Pluriavalium complex. Early and Middle Callovian ammonites have been recovered from the middle part of the Agardhfjellet Formation at the Hårfagrehaugen section (Løfaldli \& Nagy, 1980; Smelror, 1988a)

Dinoflagellate cyst assemblages recovered from the Lardyfjellet Member of the Agardhfjellet Formation at Kükenhalfjellet suggest a correlation to the Late Callovian Liesbergia scarburghensis - Wanaea thysonata concurrent range-zone and the Early Oxfordian Crussolia deflandrei - Wanaea fimbriata Oppelzone of Smelror \& Below (1992). Characteristic species recovered from these zones include Trichodinium scarburghensis, Crussolia deflandrei, Gonyaulacysta eisenackii, Gonyaulacysta jurassica subsp. adecta var. longicornis, Kalyptea diceras, Leptodinium mirabile, Lithodinia jurassica, Scriniodinium crystallinum, Stephanelytron redcliffense, Wanaea thysonata and Wanaea fimbriata (Fig. 14).

The Late Callovian-Early Oxfordian was a period of distinct diversification among the Boreal and Subboreal dinoflagellate cyst floras, as shown by an increase in the number of species compared with the older Callovian 


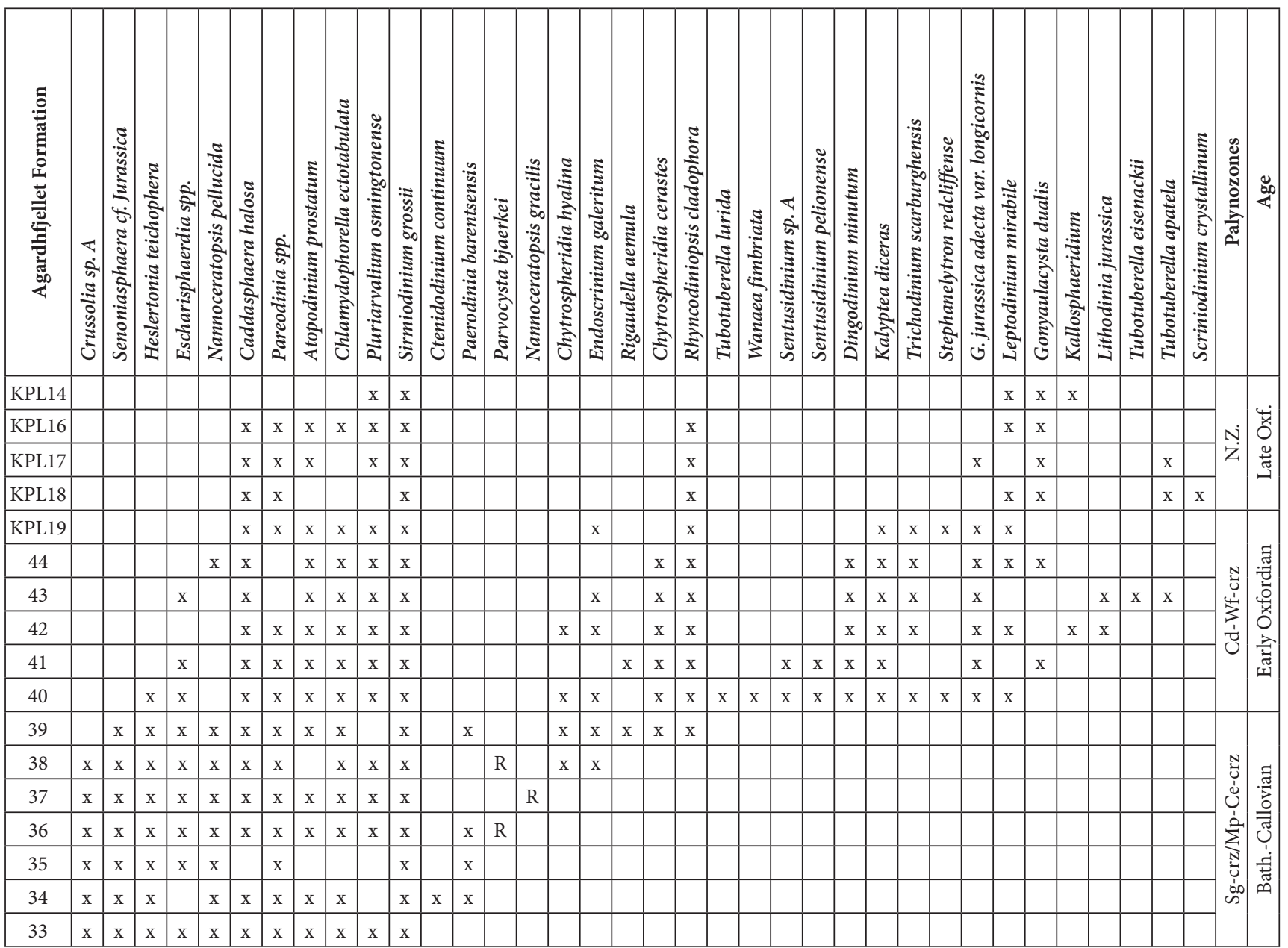

Figure 14. Range chart of palynomorphs in the Agardhfjellet Formation at Kükenthalfjellet, Kongsøya. Sg-crz= Sirmiodinium grossii concurrent range zone, $\mathrm{Mp}$-Ce-crz = Meiourogonyaulax planoseptata-Chlamydophorella ectotabulata concurrent range zone, Ls-Wt-crz = Liesbergia scarburghensis-Wanaea thysanota concurrent range zone, N.Z. = not zoned.

assemblages. The regional differences in the composition of the dinoflagellate assemblages became less prominent (Smelror, 1993) and ranges of most species are regarded as concurrent within the Arctic-NE European regions. The Late Callovian Liesbergia scarburghensis - Wanaea thysonata concurrent range-zone and the Early Oxfordian Crussolia deflandrei - Wanaea fimbriata Oppelzone defined for the Barents Sea region apparently correlates with the DSJ19-DSJ21 zones of Subboral NW Europe defined by Poulsen \& Riding (2003). The Early Oxfordian Crussolia deflandrei - Wanaea fimbriata Oppelzone further correlates with the Wanaea fimbriata Range Zone as defined in West Siberia by Ilyina et al. (2005).

Early Oxfordian ammonites (Cordioceras excavatum and $C$. aff. cordatum) are found in the upper part of the Agardhfjellet Formation at the Hårfagrehaugen section (Løfaldli \& Nagy, 1980; Smelror, 1988a). The presence of Trichodinium scarburghensis in the uppermost part of the formation suggests that deposits not younger than Middle Oxfordian are preserved at this location (Smelror, 1988a). According to Poulsen \& Riding (2003), this species does not range above the Middle Oxfordian
Tenuiserratum ammonite zone in NW Europe. Løfaldli \& Nagy (1980) suggested a Callovian-Kimmeridgian age for the upper part of the Agardhfjellet Formation based on recovered foraminifera species assigned to the Recurvoides disputabilis assemblage.

Early Kimmeridgian ammonite faunas with Amoeboceras cf. kitchini, Rasenia and Aulacostephanus have been recovered from the Agardhfjellet Formation on Svenskøya (Smith et al., 1976; Doyle \& Kelly, 1988; Ditchfield, 1997). According to Doyle \& Kelly (1988), the presence of Buchia tenuistriata in the same section suggests a Late Kimmeridgian age for the youngest sediments of the Agardhffellet Formation on Kong Karls Land.

\section{Biostratigraphy of the Tordenskjold- berget Member (Klippfisk Formation)}

The Tordenskjoldberget Member of the Klippfisk Formation (Smelror et al., 1998) was originally described 
as the 'Tordenskjoldberget Limestone Member' of the Kongsøya Formation by Smith et al. (1976). In their original description, Smith et al. (1976) also included $15 \mathrm{~m}$ of shale which is now included in the overlying Kolje Formation equivalent (Smelror et al., 1998; Dallmann, 1999).

The Tordenskjoldberget Member is a limestone unit representing the entire Klippfisk Formation on Kong Karls Land. It has only been reported from the Tordenskjoldberget on western Kongsøya, where it extends for a distance of around $1 \mathrm{~km}$ along the mountain side. The member was not sampled by Larssen et al. (1995), and the present stratigraphic subdivision and correlations are based on the data published by Verdenius (1978) and Smelror et al. (1998). The Tordenskjoldberget Member is dated as Valanginian-Hauterivian. In addition to calcareous nannofossils and dinoflagellate cysts the age determination has been based on foraminifera (Løfaldli, 1978), bivalves and belemnites (Smith et al., 1976; Kelly \& Doyle, 1988).

The Valanginian assemblage of calcareous nannofossils recovered from the lower part of the member includes abundant Watznaueria communis and common Watznaueria britannica, Crucirhabdus sp., Cretarhabdus conicus, Cretarhabdus crenulatus, Palaeopontoshpaera salebrosa and Zeugrhabdotus diplogrammus. Apparent reworked Jurassic nannoplankton has also been found in the lower part of the Tordenskjoldberget Member (Verdenius, 1978).

The belemnite fauna recovered from the Tordenskjoldberget Member contains common Early Cretaceous species (Pompeckj, 1899; Doyle \& Kelly, 1988), including Hibolithes jaculoides, Acroteuthis acmonoides and $A$. conoides which are exclusively of ValanginianHauterivian age. The bivalve fauna found in the member include Buchia keyserlingi (Blüthgen, 1936), an Early Valanginian to Early Hauterivian marker species in the Boreal Realm (Zakharov, 1981; Doyle \& Kelly, 1988).

The uppermost part of the Tordenskjoldberget Member contains a fairly diverse assemblage of Early Cretaceous dinoflagellate cysts. The co-occurrence of Valensiella magna, Dapsilidinium chems, Lithodinia pertusa, Nelchinopsis kostromiensis and Muderongia tetracantha points to a latest Hauterivian age (Smelror et al., 1998). The palynological sample also yielded several, reworked, Jurassic dinoflagellate cysts.

\section{Palynostratigaphy of the Kolje Formation equivalent}

On Kong Karls Land, the Kolje Formation equivalent is represented by $15 \mathrm{~m}$ of shale directly overlying the Tordenskjoldberget Member (sensu Smelror et al., 1998;
Dallmann, 1999). The formation is sparse in macrofossils (Doyle \& Kelly, 1988) and the foraminfera assemblages recovered by Løfaldli (1978) gave only a general Early Cretaceous age. The formation was not sampled by Larssen et al. (1995).

On Kongsøya, the Kolje Formation contains fairly rich and diverse assemblages of palynomorphs. According to Smelror et al. (1998) the recovery of the dinoflagellate cysts Pseudoceratium anaphrissum and Cerbia tabulata, together with Muderongia crucis and Rhynchodiniopsis fimbriata, suggests a late Early Barremian age for the lower part of the formation. In the stratigraphic range chart presented by Costa \& Davey (1992), Pseudoceratium anaphrissum and Cerbia tabulata only have overlapping ranges in a short interval in the rudefissicostatum ammonite zone in NW Europe. The presence of Fromea quadrugata and Muderongia pariata in the upper part of the formation suggests a Late Barremian or possibly earliest Aptian age for the youngest part of the Kolje Formation equivalent on Kong Karls Land (Smelror et al., 1998).

\section{Age of the Helvetiafjellet Formation}

On Kong Karls Land, the Helvetiafjellet Formation consists of the Hårfagrehaugen Member and the Kong Karls Land Flows (Mørk et al., 1999; Dallmann, 1999; Olaussen et al., 2018). Palynological samples from the formation included in the present study were collected from sections at Kükenhalfjellet (Fig. 15), Hårfagrehaugen and Sørstranda (Larssen et al., 1995).

A general Barremian-?Aptian age for the Helvetiafjellet Formation is suggested from its stratigraphic position. On Spitsbergen, the formation is found between Barremian strata of the uppermost Rurikfjellet Formation and the Aptian deposits of the lower Carolinefjellet Formation (Grøsfjeld, 1992; Mørk et al., 1999; Śliwińska et al., 2016). On Kong Karls Land the Hårfagrehaugen Member is overlying Upper Barremian deposits of the uppermost Kolje Formation equivalent.

The studied samples from the Hårfagrehaugen Member contain a terrestrial palynoflora of low to medium species diversity (Figs. 15, 16). The microflora of pollen and spores contains only long-ranging species of a general Early Cretaceous age, including Alisporites spp., Cicatricosisporites spp., Contignisporites cooksonii, Cyathidites australis, Deltoidospora spp., Podocarpidites spp., Lycopodiumsporites spp. and Klukisporites spp.. Redeposited Pliensbachian to Early Oxfordian dinoflagellate cysts are found at several levels.

The Kong Karls Land Flows represent two basaltic lava flows and pyroclastic rocks interfingering with the 


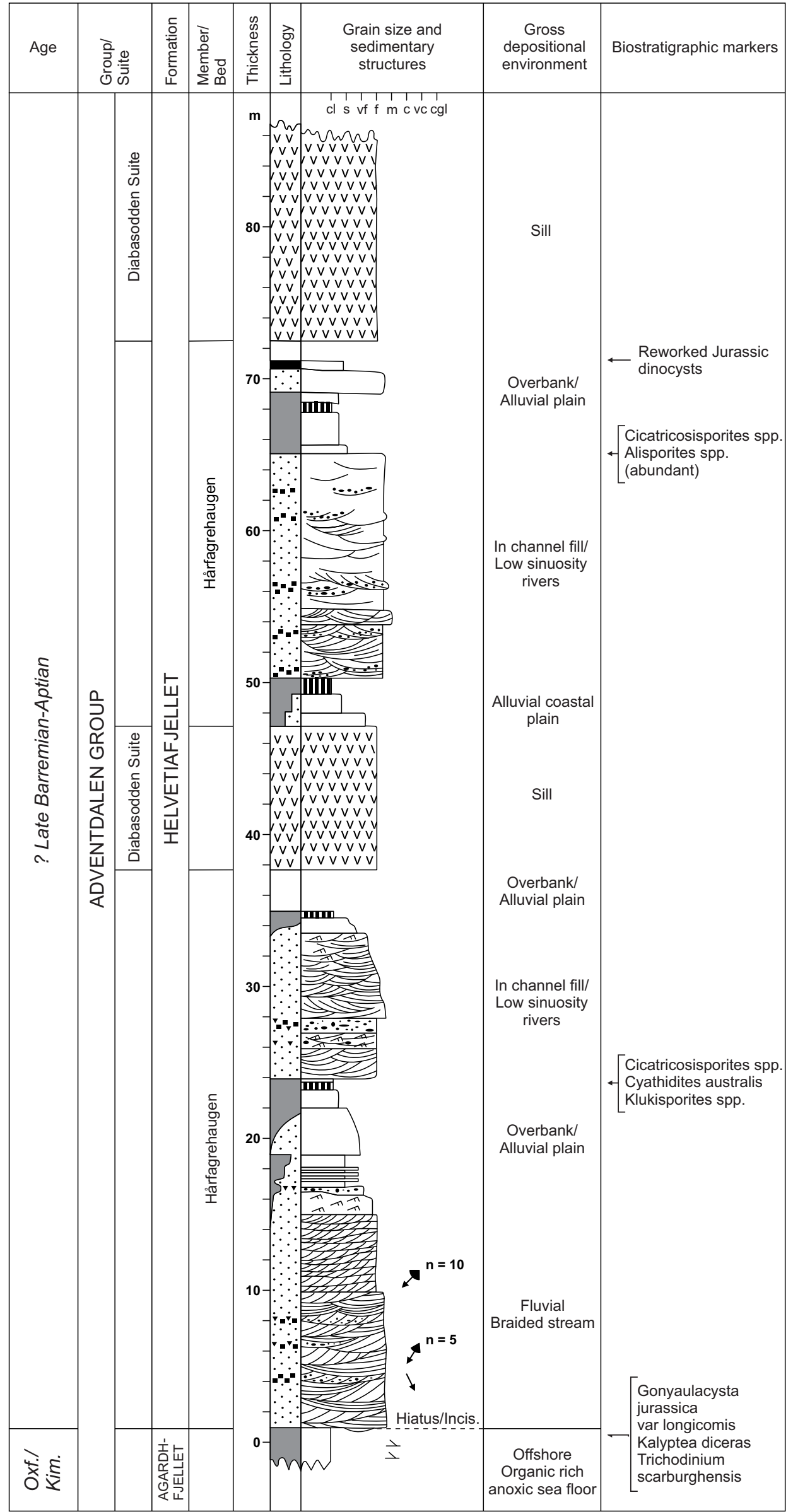

Figure 15. Lithological profile of Helvetiafjellet Formation at Kükenthalfjellet on Kongsøya, with positions of the key palynostratigraphic markers. 


\begin{tabular}{|c|c|c|c|c|c|c|c|c|c|c|c|c|c|c|c|c|}
\hline 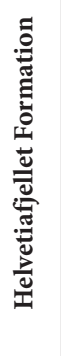 & 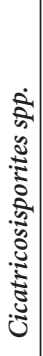 & 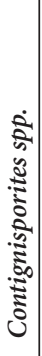 & 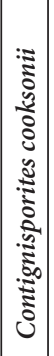 & 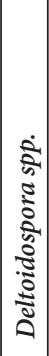 & 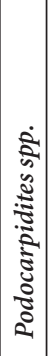 & 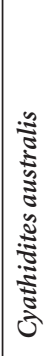 & 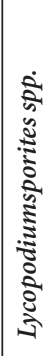 & 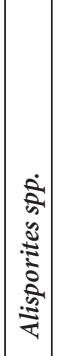 & 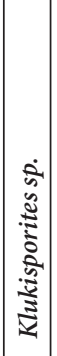 & 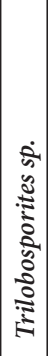 & 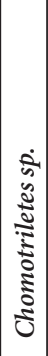 & 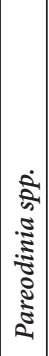 & 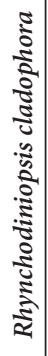 & 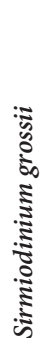 & 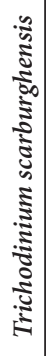 & \\
\hline 53 & & & & & & & & $\mathrm{x}$ & & & & & & & & \\
\hline 52 & & & & & & & & & & & & $\mathrm{R}$ & $\mathrm{R}$ & $\mathrm{R}$ & $\mathrm{R}$ & \\
\hline 51 & $\mathrm{x}$ & & & & & $\mathrm{x}$ & & \begin{tabular}{|l|}
$\mathrm{x}$ \\
\end{tabular} & & & $\mathrm{x}$ & & & & & \\
\hline 48 & & & & & & $\mathrm{x}$ & & & & & & & & & & \\
\hline 45 & $\mathrm{x}$ & & & $\mathrm{x}$ & & $\mathrm{x}$ & & & $\mathrm{x}$ & $\mathrm{x}$ & & & & & & \\
\hline 7 & $\mathrm{x}$ & & & $\mathrm{x}$ & $\mathrm{x}$ & & & $\mathrm{x}$ & & & & & & & & 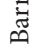 \\
\hline 5 & & & & & & $\mathrm{x}$ & $\mathrm{x}$ & & & & & & & & & \\
\hline 4 & $\mathrm{x}$ & $\mathrm{x}$ & $\mathrm{x}$ & $\mathrm{x}$ & $\mathrm{x}$ & & & & & & & & & & & \\
\hline
\end{tabular}

Figure 16. Range chart of palynomorphs in the Helvetiafjellet Formation at Kükenthalfjellet, Kongsøya. $R=$ reworked.

sediments of the Hårfagrehaugen Member. The youngest lava flow caps the Hårfagrehaugen Member sediments and represents the youngest rocks preserved on Kong Karls Land. The volcanic rocks on Kong Karls Land belong to the Late Mesozoic igneous rocks of the Arctic region commonly referred to as the High Arctic Large Igneous Province (HALIP) (Maher, 2001; Nejbert et al., 2011; Senger et al., 2014; Tegner et al., 2015; Petrov et al., 2016, Smelror \& Petrov, 2018).

Recent recorded ages of mafic sills and felsic tuff in Svalbard and Franz Josef Land show a short-lived volcanic event in Late Barremian-Early Aptian time (Corfu et al., 2013). Although less confidently dated, the Diabasodden Suite on Kong Karls Land and the Kong Karls Land Flows are an integral part of the same igneous event and province (Senger et al., 2014). Polteau et al. (2016) proposed that the magmatism on Svalbard and Franz Josef Land represents a distinct magmatic event near the Barremian/Aptian boundary (125 Ma) in the Barents Sea area resulting in the formation of the Barents Sea Sill Complex.

\section{Stratigraphic correlations to Franz Josef Land}

The Mesozoic succession on Kong Karls Land appears to be closely related to the succession on Franz Josef Land, an archipelago of 132 islands located at the northeastern edge of the Barents Shelf (Fig. 1). The main difference is that Upper Cretaceous sandstones are preserved above the
Lower Cretaceous basalts on Franz Josef Land, whereas no Upper Cretaceous rocks are preserved on Kong Karls Land (Fig. 17).

Dibner et al. (1992) described two types of stratigraphic sections on the Franz Josef Land; a rift succession consisting of a thin $(1900 \mathrm{~m})$ cover of Mesozoic and Palaeozoic strata and a non-rift succession composed of Middle Triassic to Upper Jurassic and Hauterivian sediments (up to 10-12 km thick). Both successions are unconformably overlain by Barremian to Albian basalt sheets interbedded with coal-bearing sediments. The volcanic rocks also include doleritic and gabbro-doleritic dykes and sills (Dibner et al., 1992).

Dibner (1970) divided the Mesozoic succession of Franz Josef Land into six main geological units: 1) Triassic shale-siltstones, 2) Upper Triassic-Lower Jurassic sandstone, 3) Middle-Upper Jurassic shale-siltstone, 4) Upper Jurassic-lowermost Jurassic sandstone, 5) Lower Cretaceous basalts, and 6) Upper Cretaceous sandstone. Upper Triassic rocks are exposed in outcrops, and older Triassic rocks have been documented in deep boreholes. In the Nagurskaya Borehole, a lowermost Triassic (Induan) mudstone lies directly above Upper Carboniferous limestone.

Norian siltstone and sandstone which can be correlated with the Flatsalen Formation on Kong Karls Land and Hopen have been recovered from the Graham Bell Island and Hayes Island boreholes (Dypvik et al., 1998). Comparable to what we seen on Hopen at the boundary between the De Geerdalen Formation and the overlying Flatsalen Formation, there is marked change in lithofacies from Carnian paralic deltaic sediments to Lower Norian marine shelf deposits (Basov, pers. comm., 1992).

In the Graham Bell Island borehole, Lower Norian deposits are present from $538 \mathrm{~m}$ to $799 \mathrm{~m}$ (Dypvik et al., 1998). Diverse and age-diagnostic palynomorph assemblages have been recovered from this interval, including assemblages with abundant Veryhachium spp. and Annulispora folliculosa. According to Dypvik et al. (1998), the peak abundance of Protodiploxypinus ornatus at $799 \mathrm{~m}$ suggests an Early Norian age at this level.

On Franz Josef Land there is no confirmed record of any Rhaetian deposits, and the stratigraphic break may span the Late Norian-earliest Jurassic time interval (Dypvik et al., 1998). Lower Jurassic sediments on Hayes Island (Vasilievskaya Suite) comprise sandstones, partly silty and clayey, with some gritstone interbeds. Upwards in the succession the content of clay increases. The foraminifera assemblage recovered from this unit, including Ammodiscus asper, indicate a correlation with the Ammodiscus asper Assemblage Zone of Løfaldli \& Nagy (1980) covering the upper part of the Kongsøya Formation (Basov, pers. comm., 1992). 


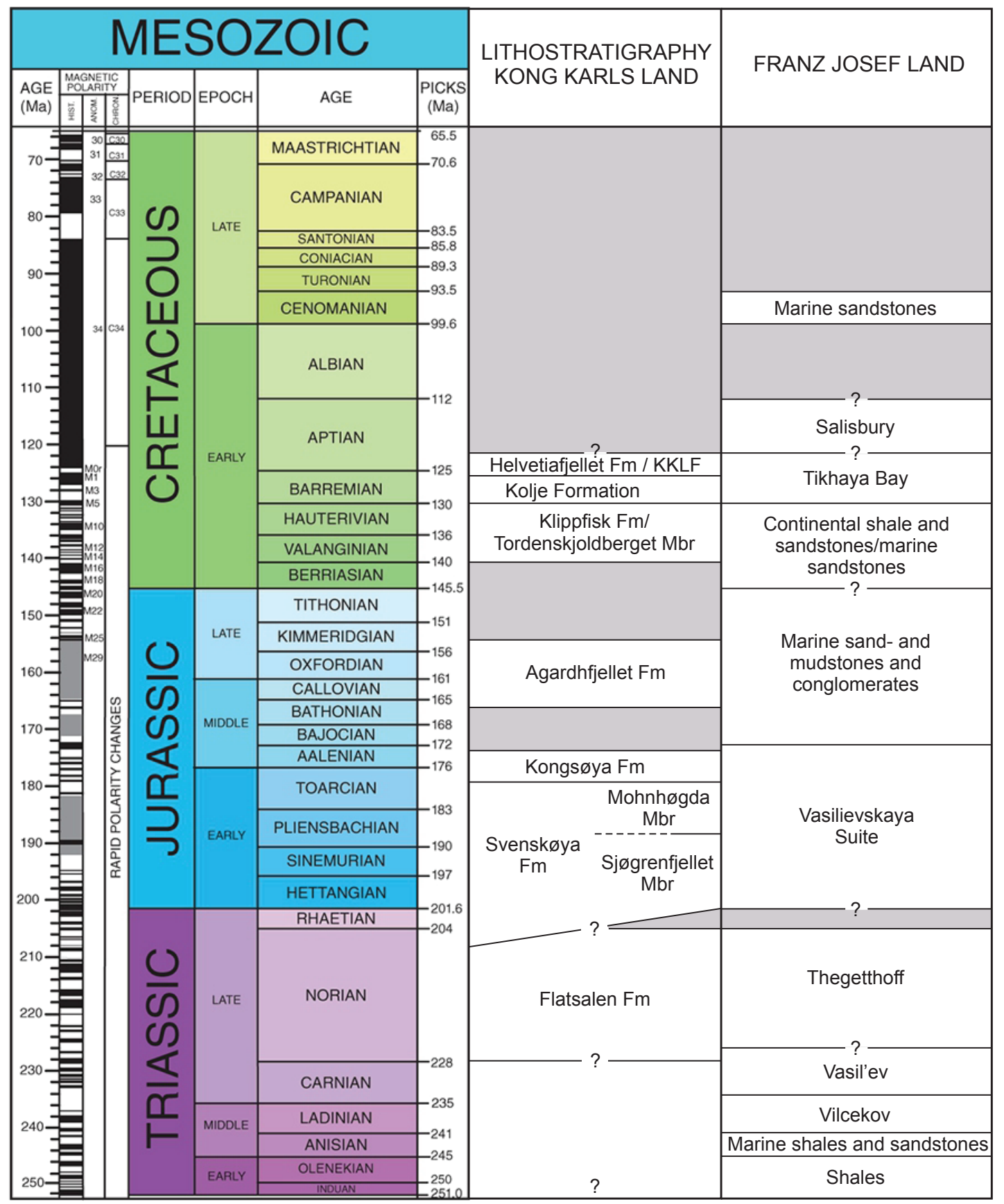

Figure 17. Lithostratigraphy of the Upper Triassic to Lower Cretaceous succession on Kong Karls Land, and correlations with the Mesozoic successions on Franz Josef Land and the Western Barents Shelf. KKLF = Kong Karls Land Flows, Fm = Formation, Mbr = Member.

According to Dibner (1961), Middle Jurassic rocks are restricted to the southwestern part of the Franz Josef Land Archipelago. The most complete section appears on Champ Island (Efremova et al., 1983). Here (Cape Fiume) there is a marked disconformity where Middle Jurassic sediments rest directly on ?Triassic sandstones. Lowermost, the Middle Jurassic deposits comprise $1 \mathrm{~m}$ of yellow quartz sand with gravels. Upwards there is a gradual transition into dark clay and silt, with interbeds of sandstone and calcareous mudstone. Ammonites of Early Aalenian age are found at $3 \mathrm{~m}, 12-13 \mathrm{~m}$ and $18 \mathrm{~m}$ above the base of the Jurassic deposits. The presence of the ammonite Arctocephalites cf. elegans in the upper part of the sequence suggests an Early Bathonian age at this level (Basov, pers. comm., 1992). The unit partly correlates to the Kongsøya Formation on Kong Karls Land.

On Northbrook Island marine Upper Aalenian sediments rest with an angular unconformity on continental Lower Jurassic deposits (Dibner \& Shulgina, 1960). Above the basal Aalenian strata there is an interval of soft clay with nodules and sandy marls (exposed 7-10 m a.s.l., Nansen, 1900), with Aalenian ammonites, belemnites and bivalves (Pompeckj, 1900; Dibner \& Shulgina, 1960). 
The following part of the section up to $113 \mathrm{~m}$ a.s.l. at Northbrook Island is covered with scree (Nansen, 1900), but the succeeding $24 \mathrm{~m}$ consists of stratified clay with phosphoritic concretions and calcareous nodules. The ammonite fauna recorded from this unit includes Arcticoceras ishmae, which provides a correlation to the Boreal Bathonian Arcticoceras ishmae zone (Kelly et al., 2015). Dinoflagellate cyst assemblages recovered from the same beds (Smelror, 1986, 1987) provide a correlation to the Sirmiodinium grossii concurrent range-zone of Smelror \& Below (1992), which is concurrent with the Arcticoceras ishmae ammonite zone. Thus, the biostratigraphy provides a good means for correlating this unit on Franz Josef Land with the lowermost Agardhfjellet Formation on Kong Karls Land (and elsewhere on Svalbard).

Further upwards in the section at Cape Flora, Upper Callovian sediments are documented by ammonites of the genus Cadoceras (Pompeckj, 1900; Dibner \& Shulgina, 1960) and dinoflagellate cyst assemblages (Smelror, 1987) characteristic of the Late Callovian Liesbergia scarburghensis - Wanaea thysonata concurrent rangezone (Smelror \& Below, 1992).

The uppermost Jurassic deposits preserved beneath the basalt at Cape Flora consist of two thin bands of black shale. A specimen of the Late Callovian ammonite Quenstediceras lamberti was found enclosed in the basalt (Nansen, 1900). The black shale and the ammonite dating suggest a correlation with the Lardyfjellet Member (Agardhfjellet Formation) on Kong Karls Land.

On Wiltchek Land Island, in southeastern Franz Josef Land, Lower Callovian brown clay (with the ammonite Cadiceras anabarsense) disconformably overlies Upper Triassic sandstones. The upper part of the clay unit contains Early Oxfordian ammonites (Cadioceras spp.) (Shulgina \& Mikhailov, 1979).

Comparable to what is observed on Kong Karls Land, Kimmeridgian-Tithonian strata are also missing at some sections at Franz Josef Land. In the western part of the archipelago, Lower Cretaceous continental sandstones directly overlie marine Lower Oxfordian clays. Upper Jurassic strata are found at Cape Lamon, Berghaus Island and at Cape Ganza on Wiltchek Land Island (Pirozhenikov, 1961). The Upper Jurassic succession consists of dark clay, with some siltstone and sand. The transition from dark clay to overlying silty-sandy deposits probably coincides with the Middle-Upper Kimmeridgian boundary. Middle Volgian (i.e., latest Middle-Late Tithonian) ammonite faunas comparable to those recorded from the Agardhfjellet Formation on Spitsbergen are recorded at Cap Lamon and Berghaus Island.

A unit of condensed carbonates comparable to the Tordenskjoldberget Member (Klippfisk Formation) on Kong Karls Land has not been recovered on Franz Josef Land. Lower Valanginian marine sandstones are known from the Klagenfurt Island and Cape Lamon (Wilchek Land Island) in the southeastern part of the archipelago. On Cape Hefer, varied sandstones with Valaginian-Hauterivian brackish-water pelecypods have been recorded (Dibner, 1957). On Champ Island Valanginian yellow sand and sandstones are overlain by sandstones with lenses of coal and a unit of clay-silt with tuff interbeds, lying directly underneath the Barremian (-Albian) basalts.

Lower Cretaceous basalts are widespread throughout the Franz Josef Land archipelago. The basalts lie unconformably on sediments of different ages, spanning from Triassic deposits in the northwest to Lower Cretaceous (Valanginian-Hauterivian) in the southeast. The igneous rocks on Franz Josef Land range from Barremian to Albian in age (Maher, 2001). The age has been confirmed by several radiometric datings, including results of analyses of basalt samples collected by Nansen in 1896 (Nansen, 1900) published by Campsie et al. (1988). A recent study of the petrology and geochemistry of doleritic sills, dykes and flood basalts from Franz Josef Land and Svalbard was reported by Tegner et al. (2015). Although age constraints remain sparse they suggested that the High Arctic Large Igneous Province was emplaced at c. 124-120 Ma on account of the presence of a mantle plume, with the centre of the plume upwelling on the Alpha Ridge north of Ellesmere Island in Arctic Canada (Tegner et al., 2015).

As on Kong Karls Land, the basalts interfinger with sandstone, siltstone and shales. The sediments commonly contain interbeds of tuffs and thin coal layers. Shale/ mudstone samples from this Early Cretaceous unit, also collected by Nansen 1896, contain palynofloras dominated by bisaccate pollen, with common Alisporites, Brachysaccus and Podocarpidites, and with minor spores (including Crybelosporits, Cicatricosporites spp., Lycopodiumsporites) (Smelror, 1986).

Based on the presence of Cicatricosporites australiensis, Cicatricosporites sp. A and abundant bisaccate pollen, Smelror (1986) suggested that the Early Cretaceous assemblage is similar to the one described as Association F by Bjærke (1977) from the Helvetiafjellet Formation on Kong Kong Karls Land. The palynological samples from Kongsøya included in the present study apparently confirm this correlation. Comparable to what is found on Kong Karls Land, the Early Cretaceous samples from Northbrook Island on Franz Josef Land also contain reworked Middle Jurassic dinoflagellate cysts (Smelror, 1986).

The youngest rocks found on Franz Josef Land are Cenomanian sandstones. No correlatable unit has been found on Kong Karls Land, where the Late BarremianAptian Helvetiafjellet Formation and the Kong Karls Land Flows are the youngest rocks preserved (Fig. 17). 

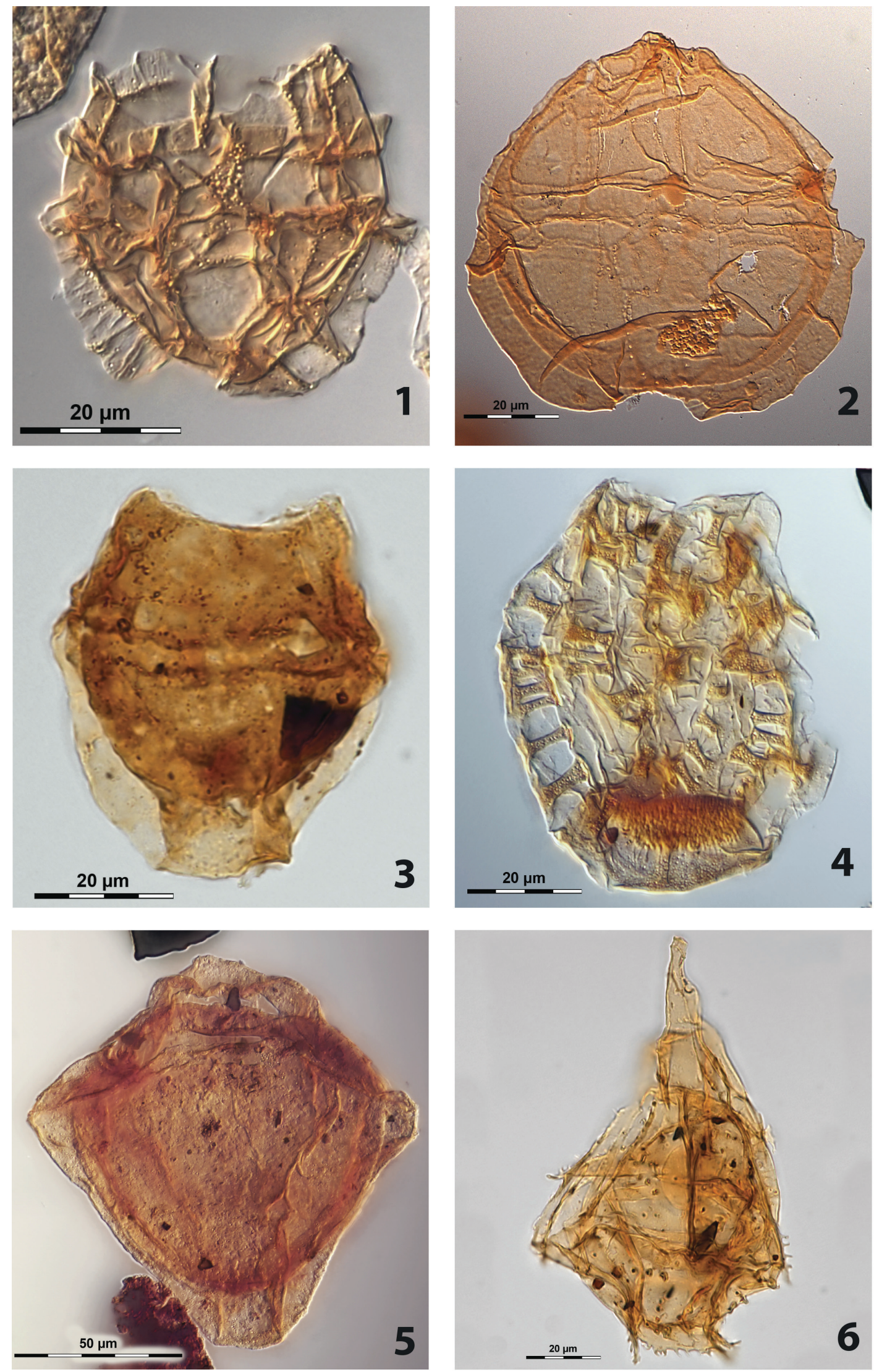

Figure 18. (1) Arkellia teichophera. Sample KÜ-34, Agardhfjellet Formation, Kükenthalfjellet, slide bQ34/0, showing the vacuolate structure of parasutural septa. (2) Sirmiodinium grossii. Sample KPL-14, Agardhfjellet Formation, Kükenthalfjellet, slide b:D46/3. (3) Dingodinium minutum. Sample KÜ-40, Agardhfjellet Formation, Kükenthalfjellet, slide bU52/4. (4) Stephanelytron redcliffense. Sample KÜ-40, Agardhfjellet Formation, Kükenthalfjellet, slide aQ53/0, multifocal processing. (5) Endoscriniodinium galleritum. Sample KÜ-42, Agardhfjellet Formation, Kükenthalfjellet, slide aH43/2, dorsal view of dorsal surface, multifocal processing. (6) Gonyaulacysta jurassica subsp. adecta var. longicornis. Sample KÜ-40, Agardhfjellet Formation, Kükenthalfjellet, slide U36/4, right lateral view of right lateral surface, multifocal processing. 

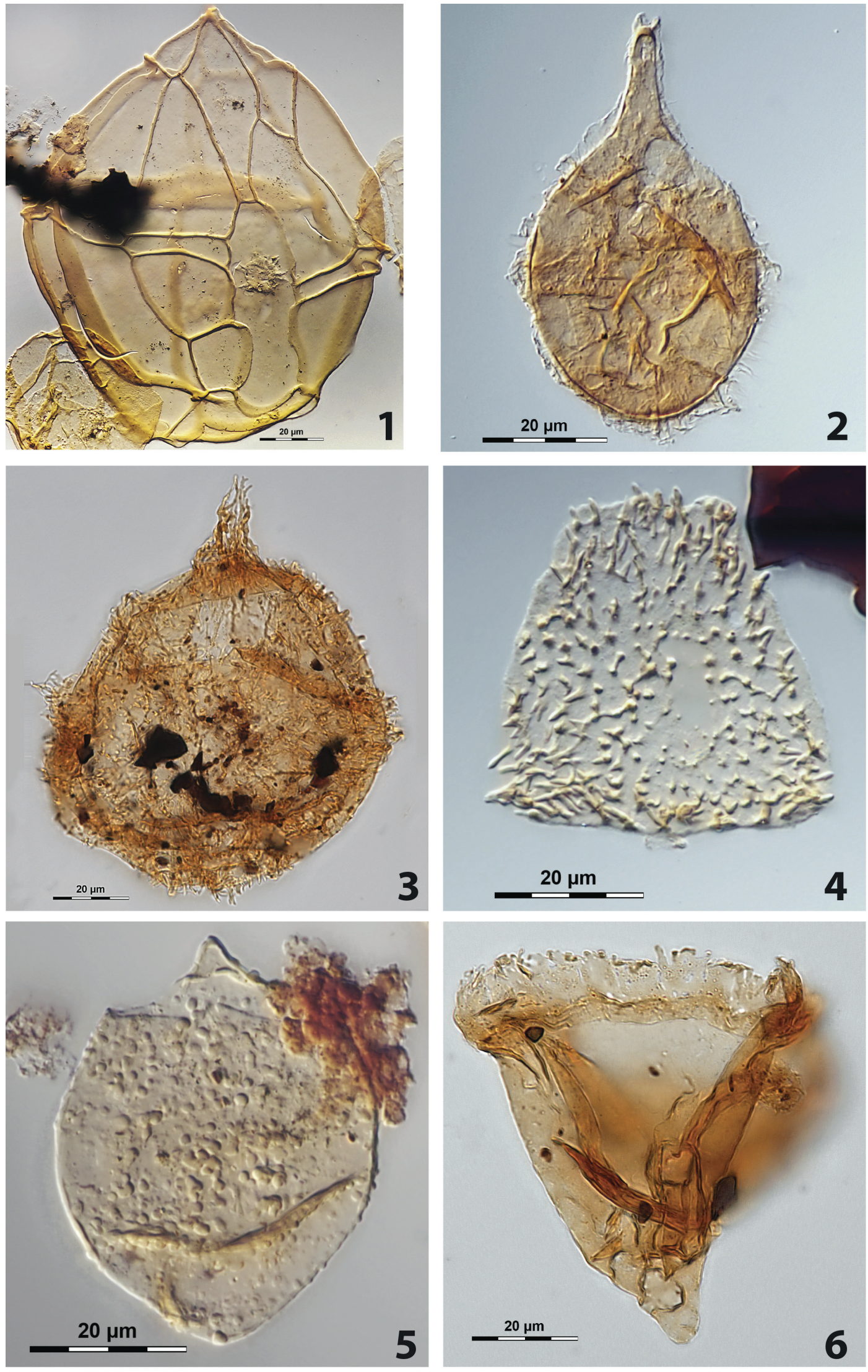

Figure 19. (1) Leptodinium mirabile. Sample KÜ-34, Agardhfjellet Formation, Kükenthalfjellet, slide bW37/4, dorsal surface, high focus. (2) Pluriarvalium sp. Sample KÜ-40, Agardhfjellet Formation, Kükenthalfjellet, slide b:N49/1. (3) Liesbergia scarburghensis. Sample KÜ-44, Agardhfjellet Formation, Kükenthalfjellet, slide b:F12/4, dorsal surface, multifocal processing. (4) Operculum of Trichodinium scarburghensis. Sample KÜ-40, Agardhfjellet Formation, Kükenthalfjellet, slide a:Q53/2. (5) Pareodinia barentsensis. Dimensions: $51 \times 41 \mu m$, Sample KÜ-34, Agardhfjellet Formation, Kükenthalfjellet, slide aQ13/3. (6) Wanaea fimbriata. Sample KÜ-40, Agardhfjellet Formation, Kükenthalfjellet, width 70 $\mu \mathrm{m}$, slide $b: U 52 / 4$. 

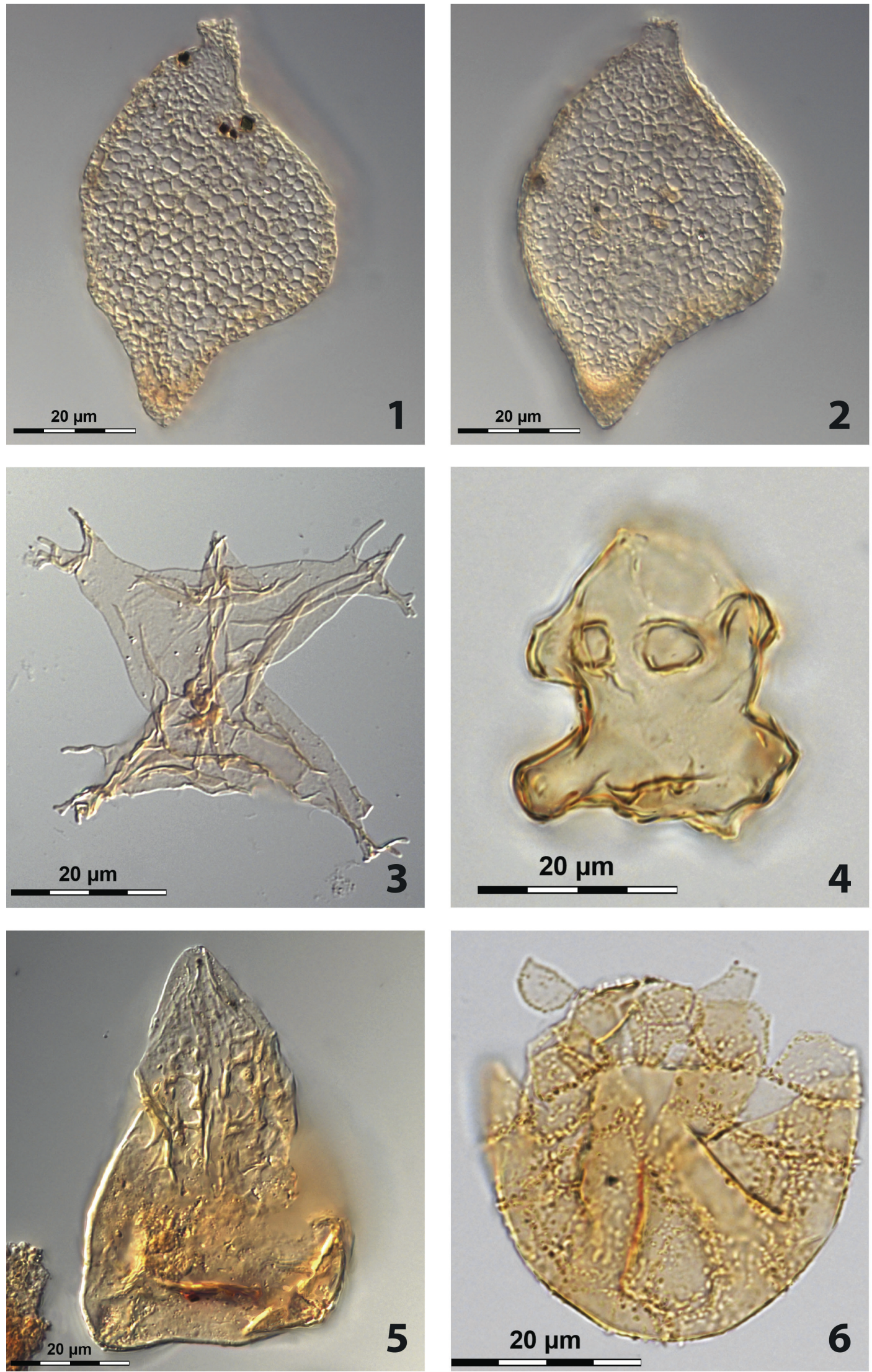

Figure 20. (1) Nannoceratopsis gracilis. Length $x$ width $=67 \mu m \times 44 \mu m$, Sample KÜ-29, Kongsøya Formation, Kükenthalfjellet, slide aJ15/1, right lateral surface, high focus. (2) Nannoceratopsis gracilis. Same specimen as 1, right lateral surface, low focus. (3) Parvocysta bjaerkei. Sample KY-32, Kongsøy Formation, Kükenthalfjellet, slide bN41/2. (4) Susadinium scrofoides. Length $x$ width $=31 \mu m x 27 \mu m$, sample KÜ-31, Kongsøya Formation, Kükenthalfjellet, slide bR17/3. (5) Phallocysta eumekes. Length $=67 \mu m$, Sample KÜ-31, Kongsøya Formation, Kükenthalfjellet, slide aG39/2. (6) Mancodinium semitabulatum. Sample KPL-3, Mohnhøgda Formation, Kükenthalfjellet, slide bN44/4. 


\section{Conclusions}

The Upper Triassic, Jurassic and Lower Cretaceous succession on Kong Karls Land contains common to abundant, well preserved, marine and terrestrial palynomorphs which are used for datings and biostratigraphic correlations of the lithostratigraphic formations and members (Figs. 18, 19 \& 20).

The palynological data suggest a correlation to the Rhaetogonyaulax rhaetica Assemblage Zone and a Norian age for the Flatsalen Formation, which constitutes the oldest deposits exposed on the islands. The overlying Svensøya Formation is dated to Norian/?Rhaetian to Early Toarcian. There are possible depositional breaks at the base of and within this formation. The palynostratigraphic data suggest that the lower Sjøgrenfjellet Member (Svenskøya Formation) can be correlated with the Norian-?Rhaetian Limbosporites lundbladii - Quadraeculina anellaeformis Assemblage Zone. The earliest/oldest appearance of Cerebropollenites thiergartii in the middle part of the Sjøgrenfjellet Member in the Harfagrehaugen section suggests a Hettangian age at this level. The lack of good biostratigraphic markers make it difficult to provide a reliable dating of the upper Sjøgrenfjellet Member and a general Hettangian to Early Pliensbachian age is inferred based on the overall composition of the palynological assemblages. The overlying Mohnhøgda Member (Svenskøya Formation) is dated as Late Pliensbachian Early Toarcian based on the recovery of dinoflagellate cysts, allowing a correlation to the DSJ6 and DSJ7 zones as defined in NW Europe.

The Kongsøya Formation is dated as Late ToarcianAalenian. The age of the formation is inferred based on correlations to the DSJ10 and Nannoceratopsis gracilis Interval Biozone (Subzones b and c) as defined in NW Europe and the British Jurassic, respectively.

There is no evidence for the presence of any Bajocian deposits on Kong Karls Land. The transgressive, oldest deposits of the Agardhfjellet Formation are dated as Bathonian based on ammonites typical of the Boreal Arctiococeras ishmae zone and dinoflagellate cysts which allow a correlation to the Sirmiodinium grossii concurrent range-zone. On Kongsøya (Hårfagrehaugen section), the palynostratigraphic data suggest that the uppermost part of the Agardhfjellet Formation is not younger than Middle Oxfordian. On Svenskøya, Early Kimmeridgian ammonite faunas and Late Kimmeridgian bivalves have been recovered from the uppermost part of the formation.

The oldest Cretaceous deposits exposed on Kong Karls Land are condensed carbonates assigned to the Tordenskjoldberget Member (Klippfisk Formation). In addition to the recovery of Hauterivian dinoflagellate cysts, the age of this member is constrained by belemnites, bivalves and calcareous nannofossils. Directly overlying the condensed unit are marine shales of the
Kolje Formation equivalent containing Late Barremian to earliest Aptian dinoflagellate cyst assemblages. The youngest rocks preserved on Kong Karls Land are fluvial deposits of the Hårfagrehaugen Member (Helvetiafjellet Formation) and the Kong Karls Land basaltic lava flows. The terrestrial palynomorphs recorded in the Håfagrehaugen Member support a Late Barremian to Aptian age for the Helvetiafjellet Formation as suggested by the $\mathrm{U}-\mathrm{Pb}$ geochronology.

Acknowledgements. The present paper is based on material collected during expeditions to Kong Karls Land arranged by Statoil in 1984 and the Norwegian Petroleum Directorate in 1993 (Larssen et al., 1995). Thanks are due to all the geologists participating in these expeditions and contributing to the observations and geological sampling. We also wish to thank Henrik Nøhr-Hansen and Atle Mørk for their constructive reviews.

\section{References:}

Ask, M. 2013: Palynological dating of the upper part of the De Geerdalen Formation on central parts of Spitsbergen and Hopen. MSc. Thesis, University of Bergen, $79 \mathrm{pp}$.

Bäckström, S.A. \& Nagy, J. 1985: Depositional history and fauna of Jurassic phosphorite conglomerate (the Brentskardhaugen Bed) in Spitsbergen. Norsk Polarinstitutt Skrifter 183, 1-61.

Bailey, D.A. 1993: Selected Cribroperidinium species (Dinophyceae) from the Kimmeridgian and Volgian of northwest Europe. Journal of Micropalaeontology 12, 219-225. https://doi.org/10.1144/jm.12.2.219.

Bailey, J.C. \& Rasmussen, M.H. 1997: Petrochemistry of Jurassic and Cretaceous tholeiites from Kong Karls Land, and their relation to Mesozoic magmatism in the Arctic. Polar Research 16, 37-62. https://doi.org/10.3402/polar.v16i1.6624.

Below, R. 1987a: Evolution und Systematik von DinoflagellatenZysten aus der Ordnung Peridiniales I. Allgemeine Grundlagen und Subfamilie Rhaetogonyaulacoideae (Familie Peridiniaceae). Palaeontographica, Abteilung B. 205, 1-164.

Below, R. 1987b: Evolution und Systematik von DinoflagellatenZysten aus der Ordnung Peridiniales II. Cladopyxiaceae und Valvaeodiniaceae. Palaeontographica, Abteilung B. 206, 1-115.

Birkenmajer, K. 1972: Magaripples and phosphorite pebbles in the Rhaeto-Liassic beds south of Van Keulenfjorden, Spitsbergen. Norsk Polarinstitutt Årbok 1970, 117-127.

Birkenmajer, K., Pugaczewska, H. \& Wierzbowski, A. 1982: The Janusfjellet Formation (Jurassic-Lower Cretaceous) at Myklegardfjellet, east Spitsbergen. Palaeontologica Polonica 43, 107-140.

Bjærke, T. 1977: Mesozoic Palynology of Svalbard II. Palynomorphs form the Mesozoic sequence of Kong Karls Land. Norsk Polarinstitutt Årbok 1976, 83-120.

Bjærke, T. 1978: Mesozoic Palynology of Svalbard III. Dinoflagellates from the Rurikfjellet Member, Janusfiellet Formation (Lower Cretaceous) of Spitsbergen. Palinologia 1, 69-93.

Bjærke, T. 1980a: Mesozoic Palynology of Svalbard V. Dinoflagellates from the Agardhfjellet Member (Middle and Upper Jurassic) in Spitsbergen. Norsk Polarinstitutts Skrifter 172, 145-167.

Bjærke, T. 1980b: Mesozoic palynology of Svalbard IV. Toarcian dinoflagellates from Spitsbergen. Palynology 4, 57-77. https://doi.org/10.1080/01916122.1980.9989202. 
Bjærke, T. \& Dypvik, H. 1977: Sedimentological and palynological studies of the Upper Triassic-Lower Cretaceous sediments in Sassenfjorden, Spitsbergen. Norsk Polarinstitutts Årbok 1976, 131150 .

Bjærke, T. \& Manum, S.B. 1977: Mesozoic Palynology at Svalbard I. The Rhaetian of Hopen, with preliminary report on the Rhaetian and Jurassic at Kong Karls Land. Norsk Polarinstitutts Skrifter 165, 1-48 pp.

Bjærke, T. \& Thusu, B. 1976: Cretaceous palynomoprphs from Spitsbergenbanken, NW Barents Shelf. Norsk Polarinstitutts Årbok 1974, 258-262.

Bjærke, T., Edwards, M.B. \& Thusu, B. 1976: Microplankton from the Janusfjellet subgroup (Jurassic- Lower Cretaceous) at Agardfjellet, Spitsbergen. A preliminary report. Norsk Polarinstitutts Årbok 1974, 63-68.

Blüthgen, J. 1936: Die Fauna und Stratigraphie des Oberjura und des Unterkreide von König Karls Land. Grimmer, Pommern, 91 pp.

Bremer, G.M.A., Smelror, M, Nagy, J. \& Vigran, J.O. 2004: Biotic responses to the Mjølnir meteorite impact, Barents Sea: Evidence from a core drilled within the crater. In Dypvik, H., Burcell, M. \& Claeys, P. (eds.): Cratering in Marine Environments and on Ice, Springer-Verlag, Berlin, Heidelberg, pp. 21-38. https://doi.org/10.1007/978-3-662-06423-8_2.

Bugge, T., Elvebakk, G., Fanavoll, S., Mangerud, G., Smelror, M., Weiss, H.W., Gjelberg, J., Kristensen, S.E. \& Nilsen, K. 2002: Shallow stratigraphic drilling applied in hydrocarbon exploration of the Nordkapp Basin, Barents Sea. Marine and Petroleum Geology 19, 13-37. https://doi.org/10.1016/S0264-8172(01)00051-4.

Campsie, J., Rasmussen, M., Hansen, N., Leibe, C., Laursen, J., BrochwiczLewinski, W. \& Johnson, L. 1988: K-Ar ages of basaltic rocks collected during a traverse on the Franz Josef Land Archipelago (1895-1896). Polar Research 6, 173-177. https://doi.org/10.3402/polar.v6i2.6858.

Corfu, F., Polteau, S., Planke, S., Faleide, J.I., Svensen, H., Zayoncheck, A., Stolbov, N. 2013: U-Pb geochronology of Cretaceous magmatism on Svalbard and Franz Josef Land, Barents Sea Large Igneous Province. Geological Magazine 150, 1127-1135.

https://doi.org/10.1017/S0016756813000162.

Costa, L. \& Davey, R.J. 1992. Dinoflagellate cysts of the Cretaceous System. In Powell, A.J. (ed.): A Stratigaphic Index of Dinoflagellate Cysts, British Micropalaeontological Society Publication Series, Chapmann \& Hall, London, pp. 99-153.

Cirilli, S. 2010: Upper Triassic-lowermost Jurassic palynology and palynostratigraphy: a review. In Lucas, S.G. (ed.): The Triassic Timescale, Geological Society London Special Publication 334, pp. 285-314. https://doi.org/10.1144/SP334.12.

Dallmann, W.K. 1999: Lithostratigraphic Lexicon of Svalbard. Norsk Polarinstitutt, Tromsø, $318 \mathrm{pp}$.

Dalseg, T.S. 2012: Palynological studies of the upper Oppdalsaita Member and Slottsmøya Member (Agardhfjellet Formation), Upper Jurassic-Lower Cretaceous in Janusfjellet and Knorringfjellet, central Spitsbergen. MSc. thesis, Department of Geosciences, University of Oslo, 107 pp.

Dalseg, T.S., Nakrem, H.A. \& Smelror, M. 2016a: Dinoflagellate biostratigraphy, palynofacies, depositional environment and sequence stratigraphy of the Agardhfjellet Formation (Upper Jurassic-Lower Cretaceous) in central Spitsbergen (Arctic Norway). Norwegian Journal of Geology 96, 119-133. https://doi.org/10.17850/njg96-2-04.

Dalseg, T.S., Nakrem, H.A. \& Smelror, M. 2016b: Organic-walled microfossils and palynodebris in cold seep carbonate deposits: The Upper Jurassic-Lower Cretaceous Agardhfjellet Formation on Svalbard (Arctic Norway). Norwegian Journal of Geology 96, 135146. https://doi.org/10.17850/njg96-2-01.

Dibner, V.D. 1957: Geologicheskoe stroenie Zemli Frantsa Josefa. Trudy NIIGA 81, 11-20.
Dibner, V.D. 1961: Stratigrafija jurskich otlozhenij Zemli Frantsa-Iosifa. Tr. Vsesojusnogo sovesttshanija po utotchneniju unifitsirovannoj schemy stratigrafii mezozoiskich otlozhenij Russkaj platform. T.2. Jurskaja sistema. Trudy VNIGNI, Gostoptechizdat, Leningrad, vyp. $29,166-171$

Dibner, V.D. 1970: Franz Josef Land and Victoria Island. In Tkachenko, B.V. \& Yegiazarov, B.Kh. (eds.): Geological Maps of the USSR, XXVI, Islands of the Soviet Arctic 26, pp. 60-107, Nedra, Moscow.

Dibner, V.D. \& Shulgina, N.I. 1960: Rezutaty stratigrafitcheskich issledovanij morskich srednejurskich I verchnejurskich otlozhenij Zemli Frantsa-Iosifa v 1953-1957. Sbornik statej po geologii Arktiki. Trudy NIIGA, tom 114, Leningrad, vyp. 14, 16-36.

Dibner, V.I., Bro, E.G., Preobrazhenskaya, E.N., Pchelina, T.M. \& Shkola, I.V. 1992: The geology of Franz Josef Land Archipelago, Russian Federation. ICAM Proceedings, p. 167-170.

Ditchfield, P.W. 1997: High northern palaeolatitude JurassicCretaceous palaeotemperature variation: new data from Kong Karls Land, Svalbard. Palaeogeography, Palaeoclimatology, Palaeoecology 130, 163-175. https://doi.org/10.1016/S0031-0182(96)00054-5.

Doyle, P. \& Kelly, R.A. 1988: The Jurassic and Cretaceous belemnites of Kong Karls Land, Svalbard. Norsk Polarinstitutts Skrifter 189, 1-77.

Dypvik, H., Hvoslef, S., Bjærke, T. \& Finnerud, E. 1985: The Wilhelmøya Formation (Upper Trissic-Lower Jurassic) at Bohemanflya, Spitsbergen. Polar Research 3, 155-165.

Dypvik, H., Nagy, J., Eikeland, T.A., Backer-Owe, K., Andresen, A., Haremo, P., Bjærke, T., Johansen, H. \& Elverhøi, A. 1991: The Janusfjellet Subgroup (Bathonian-Hauterivian) on central Spitsbergen: a revised lithostratigarphy. Polar Research 9, 21-43. https://doi.org/10.3402/polar.v9i1.6777.

Dypvik, H., Sokolov, A., Pčelina, T., Fjellså, B., Bjærke, T., Korchinskaja, M. \& Nagy, J. 1998: The Triassic succession of Franz Josef Land, stratigraphy and sedimentology of three wells from Alexandra, Hayes and Graham Bells islands. Norsk Polarinstitutt Meddelelser 151, 50-82.

Dypvik, H., Mørk, A., Smelror, M., Sandbakken, P.T., Tsikalas, F., Vigran, J.O., Bremer, G.M.A., Nagy, J., Gabrielsen, R.H., Faleide, J.I., Bahiru, G.M. \& Weiss, H.M. 2004: Impact breccia and ejecta from the Mjølnir crater in the Barents Sea - The Ragnarok Formation and Sindre Bed. Norwegian Journal of Geology 84, 143-167.

Dypvik, H., Smelror, M., Sandbakken, P.T., Salvigsen, O. \& Kalleson, E. 2006: Traces of the marine Mjølnir impact event. Palaeogeography, Palaeoclimatology, Palaeoecology 241, 621-636. https://doi.org/10.1016/j.palaeo.2006.04.013.

Efremova, V.I., Meledina, S.V. \& Nalnjaeva, T.I. 1983: Jurskie golovonogie s ostrova Tschamp (Zemlja Frantsa-Iosifa). Mezozoj Sovetskoj Arktiki. Tr. IGiG AN SSSR, Nauka, Novosibirsk, 125-137.

Fiksdal,B. 1988: Palynologiske undersøkelser av Wilhelmøyaformasjonens øvre del på Kong Karls Land, Svalbard. Hovedfagsoppgave i Botanikk, Prekvartær biostratigrafi, Universitetet i Trondheim, 96 pp.

Gjelberg, J., Dreyer, T., Høie, A., Tjelland, T. \& Lilleng, T. 1987: Late Traissic to Mid-Jurassic sandbody development on the Barents and Mid-Norwegian Shelf. In Spencer, A.M., Holter, E., Campell, C.J., Hanslien, S.H., Nelson, P.H.H., Nysaether, E. \& Ormaasen, E.G. (eds.): Petroleum Geology of Northwest Europe, Graham \& Trotman, London, pp. 1105-1129.

Grundvåg, S.A., Marin, D., Kairanov, B., Śliwińska, K.A., Nøhr-Hansen, H., Jelby, M.E, Escalona, A. \& Olaussen, S. 2017: The Lower Cetaceous succession of the northwestern Barents Shelf: Oshore and offshore correlations. Marine and Petroleum Geology 86, 834-857. https://doi.org/10.1016/j.marpetgeo.2017.06.036.

Grøsfjeld, K. 1992: Palynological age constraints on the base of the Helvetiafjellet Formation (Barremian) on Spitsbergen. Polar Research 11,11-19. https://doi.org/10.3402/polar.v11i1.6713.

Harland, W.B. 1973: Mesozoic geology of Svalbard. American Association of Petroleum Geologists Memoir 19, 135-148. 
Henriksen, E., Ryseth A.E., Larssen, G.B., Heide, T., Rønning, K., Sollid, K., Stoupakova, A.V. 2011: Tectonostratigraphy of the greater Barents Sea: implications for petroleum systems. In Spencer, A.M., Embry, A.F., Gautier, D.L., Stoupakova, A.V. \& Sørensen, K. (eds.) Arctic Petroleum Geology, Geological Society of London Memoir 35, pp. 163-195. https://doi.org/10.1144/M35.10.

von Hillebrandt, A., Krystyn, L. \& Kuerschner, W. 2007: A candidate GSSP for the base Jurassic in the Northern Calcareous Alps (Kujoch section, Karwendel Mountains, Tyrol, Austria). International Subcommission on Jurassic Stratigraphy Newsletter 34, 2-20.

Hochuli, P.A. \& Vigran, J.O. 2010: Climatic variations in the Boreal Triassic - Inferred from palynological records from the Barents Sea. Palaeogeography, Palaeoclimatology, Palaeoecology 290, 20-42. https://doi.org/10.1016/j.palaeo.2009.08.013.

Hochuli, P., Colin, P.A. \& Vigran, J.O. 1989: Triassic biostratigraphy of the Barents Sea area. In Collinson, J.D. (ed.): Correlation in Hydrocarbon Exploration, Graham \& Trotman, London, pp. 131153. https://doi.org/10.1007/978-94-009-1149-9_12.

Holen, L.H. 2014. Late Triassic (Carnian) palynology of the Northern Barents Sea (Sentralbanken High). MSc. Thesis, University of Bergen, Norway, 1-96 pp.

Ilyina, V.I., Nikitenko, B.L. \& Glinskikh, L.A. 2005: Foraminifera and dinoflagellate cyst zonation and stratigraphy of the Callovian to Volgian reference section in the Tyumenskaya superdeep well (West Siberia, Russia). In Powell, A.J. \& Riding, J.B. (eds.): Recent Development in Applied Biostratigraphy, The Micropalaentological Society, Special Publications, pp. 109-144.

Johannessen, E.P. \& Embry, A. 1989: Sequence correlation: Upper Triassic to Lower Jurassic succession, Canadian and Norwegian Arctic. In Collison, J.D. (ed.): Correlation in Hydrocarbon Exploration. Norwegian Petroleum Society (Graham \& Trotman), pp. 155-170. https://doi.org/10.1007/978-94-009-1149-9_13.

Kelly, S.R.A. 1988: Jurassic through Cretaceous Stratigraphy of the Barents Shelf. In W.B. Harland \& E.K. Dowdeswell (eds.): Geological Evolution of the Barents Shelf Region, Graham \& Trotman, pp. 109130.

Kelly, S.R.A., Gregory, F.J., Braham, W., Strogen, D.P. \& Whitham, A.G. 2015: Towards an integrated Jurassic biostratigraphy for eastern Greenland. Volumina Jurassica XXXI, 43-64.

Kopik, J. \& Wierzbowski, A. 1988: Ammonites and stratigraphy of the Bathonian and Callovian at Janusfellet and Wimanfjellet, Sassenfjorden, Spitsbergen. Palaeontologica 33, 145-168.

Korčinskaya, M.V. 1980: Geology of the sedimentary platform cover of the archipelago Svalbard. NIIGA., Leningrad, 30-43 (In Russian).

Krajewski, K. 1992: Phosphorite-bearing succession of the Wilhelmøya Formation at Hornsund and along the western coast of Sørkapp Land, Spitsbergen. Studia Geologica Polonica 98, 201-233.

Landa, J. 2015: Middle to Late Triassic (late Ladinian - late Carnian) palynology of the shallow stratigraphic core 7534/4-U-1, Sentralbanken High, Northern Barents Sea. MSc. Thesis, University of Bergen, 91 pp. Larssen, G.B., Dahlgren, S., Eliassen, P.E., Fjæringstad, V., Hanesand, T., Hansen, S., Helland-Hansen, W., Heintz, N., Høy, T., Johannessen, E.P., Nøttvedt, A., Olaussen, S., Riis, F., Rundberg, Y., Rømuld, A. \& Williams, R.W. 1995: Kong Karls Land ekspedisjonen 1993. Sentrias til tidligkrit geologisk utvikling av Kong Karls Land, nordlige Barentshav. Bind I: 216 pp., Bind II: 20 Appendices.

Lord, G.S., Solvi, K.H., Ask, M., Mørk, A., Hounslow, M-W. \& Paterson, N.W. 2014: The Hopen Member: A new lithostratigraphic unit on Hopen and equivalent to the Isforden Member of Spitsbergen. Norwegian Petroleum Directorate Bulletin 11, 81-96.

Lord, G.S., Mørk, M.E.B., Mørk,A.\& Olaussen, S. in press: Sedimentology and petrology of the Svenskøya Formation on Hopen, Svalbard: An analogue to sandstone reservoirs in the Realgrunnen Subgroup. Polar Research.

Løfaldli, M. 1978: Early Cretaceous foraminifera from the Janusfjellet Formation in Kong Karls Land, eastern Svalbard. Norsk Polarinstitutts Årbok 1977, 345-350.
Løfaldli, M. \& Nagy, J. 1980: Foraminiferal stratigraphy of Jurassic deposits on Kongsøya, Svalbard. Norsk Polarinstitutts Skrifter 172, 63-95.

Maher, H.D. Jr. 2001: Manifestations of the Cretaceous High Arctic Large Igneous Province in Svalbard. The Journal of Geology 109, 91-104. https://doi.org/10.1086/317960.

Maher, M.D. 1989: A storm-related origin for the Jurassic Brentskardhaugen Bed of Spitsbergen, Norway. Polar Research 7, 67-77. https://doi.org/10.3402/polar.v7i1.6831.

Mangerud, G. \& Rømuld, A. 1991. Spathian e Anisian (Triassic) palynology at the Svalis Dome, southwestern Barents Sea. Review of Palaeobotany and Palynology 70, 199-216. https://doi.org/10.1016/0034-6667(91)90002-K.

Meltveit, A.R. 2015: Middle to Late Triassic (Ladinian to Carnian) palynology of shallow stratigraphic cores 7831/2-U-2 and 7831/2-U-1, offshore Kong Karls Land, Norwegian Arctic. MSc. Thesis, University of Bergen, 81 pp.

Midtkandal, I., Svendsen, H., Planke, S., Corfu, F., Polteau, S., Torsvik, T.H., Faleide, J.I., Grundvåg, S.A., Selnes, H., Kürschner, W.M. \& Olaussen, S. 2016: The Aptian (Early Cretaceous) oceanic anoxic event (OAE1a) in Svalbard, Barents Sea, and the absolute age of the Barremian-Aptian boundary. Palaeogeography, Palaeoclimatology, Palaeoecology 463, 126-135.

https://doi.org/10.1016/j.palaeo.2016.09.023.

Mueller, S., Veld, H., Nagy, J., Kürschner, W.M. 2014: Depositional history of the Upper Triassic Kapp Toscana Group on Svalbard, Norway, inferred from palynofacies analysis and organic geochemistry. Sedimentary Geology 310, 16-29. https://doi.org/10.1016/j.sedgeo.2014.06.003.

Mueller, S., Hounslow, M.W., Kürschner, W.M. 2016: Integrated stratigraphy and alaeoclimate history of the Carnian pluvial event in the Boreal Realm; new data from the Upper Triassic Kapp Toscana Group in central Spitsbergen (Norway). Journal of Geological Society 173, 186-202. https://doi.org/10.1144/jgs2015-028.

Mørk, A. \& Smelror, M. 2001: Correlation and non-correlation of High Order Circum-Arctic Mesozoic Sequences. Polarforschung 69, 65-72.

Mørk, A., Knarud, R. \& Worsley, D. 1982: Depositional and diagenetic environments of the Triassic and Lower Jurassic of Svalbard. In Embry, A.F. \& Balkwill, H.R. (eds.): Arctic Geology and Geophysics, Canadian Society of Petroleum Geologists Memoir 8, pp. 371-398.

Mørk, A., Vigran, J.O., Korchinskaya, M.V., Pchelina, T.M., Fefilova, L.A., Vavilov, M.N. \& Weitschat, W. 1993: Triassic rocks in Svalbard, the Arctic Soviet islands and the Barents Shelf: bearing on their correlations. In Vorren, T., Bergsager, E., Dahl-Stamnes, Ø.A., Holter, E., Johansen, B., Lie, E. \& Lund, T.B. (eds.): Arctic Geology and Petroleum Potential, Norwegian Petroleum Society Special Publication 2, pp. 457-479. https://doi.org/10.1016/B978-0-444-88943-0.50033-2.

Mørk, A., Dallmann, W.K., Dypvik, H., Johannessen, E.P., Larssen, G.B., Nagy, J., Nøttvedt, A., Olaussen, S., Pcelina, T.M. \& Worsley, D. 1999: Mesozoic Lithostratigraphy. In Dallmann, W.K. (ed.): Lithostratigraphic Lexicon of Svalbard, Norsk Polarinstitutt Tromsø, pp. 127-214.

Nagy, J. \& Berge, S.H. 2008: Micropalaeontological evidence of brackish water conditions during deposition of the Knorringfjellet Formation, Late Triassic-Early Jurassic, Spitsbergen. Polar Research 27, 413-427. https://doi.org/10.1111/j.1751-8369.2007.00038.x.

Nansen, F. 1900: Geological sketch of Cape Flora and its neighbourhood. In Nansen, F. (ed.): Scientific Results of the Norwegian North Polar Expedition 1893-96, part. 1, no. 2, The Fridtjof Nansen Fund, pp. $1-32$.

Nathorst, A.G. 1901: Bidrag til Kong Karls Lands geologi. Geologiska Föreningen i Stockholm, Förhandlingar 23, 341-378. https://doi.org/10.1080/11035890109444343.

Nathorst, A.G. 1910: Beiträge zur Geologie der Bäreninsel, Spitzbergen und des Köning-Karl-landes. Bulletin Geologiska Institutionen Universitetet $i$ Uppsala 10, 261-416. 
Nejbert, K., Krajewski, K.P., Dubińska, E., Pécskay, Z., 2011: Dolerites of Svalbard, north-west Barents Sea Shelf: age, tectonic setting and significance for geotectonic interpretation of the High-Arctic Large Igneous Province. Polar Research 30, 1-24.

https://doi.org/10.3402/polar.v30i0.7306.

Nøttvedt, A., Cecchi, M., Gjelberg, J.G., Kristensen, S.E., Lønøy, A., Rasmussen, A., Rasmussen, E., Skott, P.H. \& van Veen, P.M. 1992: Svalbard-Barents Sea correlation: a short review. In Vorren, T., Bergsager, E., Dahl-Stamnes, Ø.A., Holter, E., Johansen, E., Lie, B. \& Lund, T.B. (eds.): Arctic Geology and Petroleum Potential. Norwegian Petroleum Society Special Publication 2, pp. 363-375.

Olaussen, S., Dalland, A., Gloppen, T.G. \& Johannessen, E.P. 1984: Depositional environment and diagnosis of Jurassic reservoir sandstone in the eastern part of Troms I area. In Spencer, A.M., Johnsen, S.O., Mørk, A., Nysaether, E., Songstad, P. \& Spinnanger, Å. (eds.): Petroleum geology of the Northwest Europe: Proceedings of the North European Margin Symposium, Graham \& Trotman, London, pp. 61-79.

Olaussen, S., Larssen, G.B., Helland-Hansen, W, Johannessen, E. P., Nøttvedt, A., Riis, F., Rismyhr, B., Smelror, M. \& Worsley, D. 2018. Mesozoic strata of the Kong Karls Land archipelago, Arctic Norway: a link to the northern Barents Sea basins. Norwegian Journal of Geology, in press.

Parker, J.R. 1967: The Jurassic and Cretaceous sequence in Spitsbergen. Geological Magazine 104, 487-505. https://doi.org/10.1017/S0016756800049220.

Paterson, N.W. \& Mangerud, G. 2015: Late Triassic (Carnian-Rhaetian) palynology of Hopen, Svalbard. Review of Palaeobotany and Palynology 220, 98-119.

https://doi.org/10.1016/j.revpalbo.2015.05.001.

Paterson, N.W. \& Mangerud, G. 2017: Palynology and depositional environments of the Middle-Late Triassic (Anisian-Rhaetian) Kobbe, Snadd and Fruholmen formations, southern Barents Sea, Arctic Norway. Marine and Petroelum Geology 86, 304-324.

https://doi.org/10.1016/j.marpetgeo.2017.05.033.

Paterson, N.W., Mangerud, G. \& Mørk, A. 2016a: Late Triassic (early Carnian) palynology of shallow stratigraphical core 7830/5-U-1, offshore Kong Karls Land, Norwegian Arctic. Palynology 41, 230254. https://doi.org/10.1080/01916122.2016.1163295.

Paterson, N.W., Mangerud, G., Cetean, C.G., Mørk, A., Lord, G.S., Klausen, T.G., Mørkved, P.T. 2016b. A multidisciplinary biofacies characterisation of the Late Triassic (late Carnian-Rhaetian) Kapp Toscana Group on Hopen, Arctic Norway. Palaeogeography, Palaeoclimatology, Palaeoecology 464, 16-42.

https://doi.org/10.1016/j.palaeo.2015.10.035.

Pčelina, T.M. 1980: New evidence on the Triassic/Jurassic boundary beds on Svalbard. In Semevskij, D.V. (ed.): Geology of the sedimentary cover of Svalbard. NIIGA, Leningard (In Russian).

Petrov, O.V., M., Morozov, A., Shokalsky, S., Kushbin, S., Artemieva, I.M., Sobolev, N., Petrov, E., Ernst, R.E., Sergeey, S. \& Smelror, M. 2016. Crustal structure and tectonic model of the Arctic region. Earth-Sciences Reviews, 154, 29-71.

Pirozhnikov, L.P. 1961: Morskoj niznij volzkij yarus ostrova Berkhaus (archipelago Zemlya Frantsa-iosifa). Doklady Akademii Nauk United States, tom 140, NS, 912-915.

Polteau, S., Hendriks, B.W.H., Planke, S., Ganerød, M., Corfu, F., Faleide, J.I., Midtkandal, I., Svensen, H. \& Myklebust, R. 2016: The Early Cretaceous Barents Sea Sill Complex: Distribution, ${ }^{40} \mathrm{Ar} /{ }^{39} \mathrm{Ar}$ Geochronology, and Implications for Carbon Gas Formation. Palaeogeography, Palaeoclimatology, Palaeoecology 441, 83-95. https://doi.org/10.1016/j.palaeo.2015.07.007.

Pompeckj, J.F. 1899: Marines Mesozoicum von König Karls Land. Öfvers, Kungliga Vetenskaps Akademi Förhandlingar Stockholm 56, 449-464.

Pompeckj, J.F. 1900: The Jurassic fauna of Cape Flora, Franz Josef Land. In Nansen, F. (ed.): Scientific Results of the Norwegian North Polar Expedition 1893-96, part. 1, no. 2, The Fridtjof Nansen Fund, pp. 33-147.
Poulsen, N.E. 1992: Jurassic dinoflagellate cyst biostratigraphy of the Danish Subbasin in relation to sequences in England and Poland: a preliminary review. Review of Palaeobotany and Palynology 75, 33-52. https://doi.org/10.1016/0034-6667(92)90148-A.

Poulsen, N.E. 1996: Dinoflagellate cysts from marine Jurassic deposits of Denmark and Poland, Series 31. American Association of Stratigarphic Palynologists Contributions, 227 pp.

Poulsen, N.E. \& Riding, J.B. 2003: The Jurassic dinoflagellate cyst zonation of Subboreal Northwest Europe. Geological Survey of Denmark and Grønland Bulletin 1, 115-144.

Prauss, M. 1989: Dinozysten-Strategraphie und Palynofazies im Oberen Lias und Dogger von NW-Deutschland. Palaeontographica B 214, 1-124.

Radmacher, W., Tyszka, J. \& Mangerud, G. 2014a: Distribution and biostratigraphic significance of Heterosphaeridium bellii sp. nov. and other Late Cretaceous dinoflagellate cysts from the southwestern Barents Sea. Review of Palaeobotany and Palynology 201, 29-40. https://doi.org/10.1016/j.revpalbo.2013.10.003.

Radmacher, W., Tyszka, J., Mangerud, G. \& Pearce, M.A. 2014b: Dinoflagellate cyst biostratigraphy of Upper Albian to Lower Maastrichtian in the southwestern Barents Sea. Marine and Petroleum Geology 57, 109-121. https://doi.org/10.1016/j.marpetgeo.2014.04.008.

Rawson, P.F. 1982: New Arctocephalitinae (Ammonoidea) from the Middle Jurassic of Kong Karls Land. Geological Magazine 119, 95100. https://doi.org/10.1017/S0016756800025693.

Riding, J.B. 1984: A palynological investigation of Toarcian to early Aalenian strata from the Blea Wyke area, Ravenscar, North Yorkshire. Proceedings of the Yorkshire Geological Society 45, 109-122. https://doi.org/10.1144/pygs.45.1-2.109.

Riding, J.B. \& Thomas, J.E. 1992: Dinoflagellate cysts of the Jurassic System. In Powell, A.J. (ed.): A Stratigaphic Index of Dinoflagellate Cysts, British Micropalaeontological Society Publication Series, Chapmann \& Hall, London, pp. 7-97.

https://doi.org/10.1007/978-94-011-2386-0_2.

Rismyhr, B., Bjærke, T. \& Olaussen, S.. Mulrooney, M.J. \& Senger, K. in press. Facies, palynostratigraphy and sequence stratigraphy of the Wilhelmøya Subgroup (Upper Triassic-Middle Jurassic) in western central Spitsbergen, Svalbard. Norwegian Journal of Geology.

Senger, K., Tveranger, J., Ogata, K., Braathen, A. \& Planke, S. 2014: Late Mesozoic magmatism in Svalbard: A review. Earth-Science Reviews 139, 123-144. https://doi.org/10.1016/j.earscirev.2014.09.002.

Shulgina, N.I. \& Michailov, Ju.A. 1979: Novye dannye po stratigraphii mezozoiskich otlozhenij Zemli Frantsa-Iosifa. Verchnij paleozoj i mezozoj ostrovov i poberezhja Arktitcheskich morej SSSR. Izdatel'stvo NIIGA, 1-9.

Śliwińska, K.A., Nøhr-Hansen, H., Grundvåg, S.A., Jelby, M.E, Marin, D., Escalona, A. \& Olaussen, S. 2016: Dinocyst biostratigraphy of the Lower Cretaceous succession of Spitsbergen and the SW Barents Shelf. NPF Onshore-Offshore relationships of the North Atlantic Margins. Abstracts and Proceedings, Norwegian Geological Society, 18-19 October, Trondheim, Norway, p. 72-73.

Smelror, M. 1986: Jurassic and Lower Cretaceous palynomorph assemblages from Cape Flora, Franz Josef Land, Arctic USSR. Norsk Geologisk Tidsskrift 66, 107-119.

Smelror, M. 1987: Bathonian and Callovian (Middle Jurassic) dinoflagellate cysts and acritarchs from Franz Josef Land, Arctic Soviet. Polar Research 5, 221-238.

https://doi.org/10.3402/polar.v5i2.6878.

Smelror, M. 1988a: Bathonian to Early Oxfordian dinoflagellate cysts and acritarchs from Kong Karls Land, Svalbard. Review of Palaeobotany and Palynology 56, 275-304. https://doi.org/10.1016/0034-6667(88)90061-9.

Smelror, M. 1988b: Late Bathonian to Early Oxfordian dinoflagellate cyst stratigraphy of Jameson Land, East Greenland. Rapport Grønlands Geologiske Undersøgelse 137, 135-159. 
Smelror,M.1989: Chlamydophorella ectotabulata sp.nov., a gonyaulacoid dinoflagellate cyst from the Late Bathonian to the Oxfordian of the Arctic. Review of Palaeobotany and Palynology 61, 139-145.

https://doi.org/10.1016/0034-6667(89)90066-3.

Smelror, M. 1991: Two new dinoflagellate cysts from the Middle Jurassic of the Barents Sea Region. Journal of micropalaeontology 10, $175-180$.

Smelror, M. 1993: Biogeography of Bathonian to Oxfordian (Jurassic) dinoflagellates: Arctic, NW Europe and circum-Mediterranean regions. Palaeogeography, Palaeoclimatology, Palaeoecology 102, 121160. https://doi.org/10.1016/0031-0182(93)90009-8.

Smelror, M. \& Aarhus, N. 1989: Emendation of the dinoflagellate cyst genus Crussolia Wolfard \& van Erve 1981, and description of C. dalei n.sp. from the Callovian of Svalbard. Neues Jahrbuch für Geologie und Paläontologie H.1, 37-46.

Smelror, M. \& Below, R. 1992: Dinoflagellate biostratigraphy of the Toarcian to Lower Oxfordian (Jurassic) of the Barents Sea region. In Vorren, T., Bergsager, E., Dahl-Stammes, Ø.A., Holter, E., Johansen, B., Lie, E. \& Lund, T.B. (eds.): Arctic Geology and Petroleum Potential, Norwegian Petroleum Society Special Publication 2, pp. 495-513.

Smelror, M. \& Dypvik, H. 2005: Marine microplankton biostratigraphy of the Volgian-Ryazanian boundary strata, western Barents Shelf. Norges Geologiske Undersøkelse Bulletin 443, 61-69.

Smelror, M. \& Dypvik, H. 2006: The sweet aftermath: Environmental changes and biotic restoration following the marine Mjølnir impact (Volgian-Ryazanian boundary, Barents Shelf). In Cockell, C.S., Koeberl, C. \& Gilmour, I. (eds.): Biologial Processes Associated with Impact Events, Springer Verlag, Berlin, pp. 143-178.

https://doi.org/10.1007/3-540-25736-5_7.

Smelror, M. \& Larssen, G.B. 2016: Are there Upper Cretaceous sedimentary rocks preserved on Sørkapp Land, Svalbard? Norwegian Journal of Geology 96, 147-158. https://doi.org/10.17850/njg96-2-05.

Smelror, M. \& Petrov, O.V. 2018. Geodynamics of the Arctic: From Proterozoic orogens to present day seafloor spreading. Journal of Geodynamics, https://doi.org/10.1016/j.jog.2018.09.006

Smelror, M., Mørk, A., Monteil, E., Rutledge, D., Leereveld, H., 1998: The Klippfisk Formation - a lithostratigraphic unit of Lower Cretaceous platform carbonates on the Western Barents Shelf. Polar Research 17, 181-202. https://doi.org/10.1111/j.1751-8369.1998.tb00271.x.

Smelror, M., Kelly, S.R.A., Dypvik, H., Mørk, A., Nagy, J. \& Tsikalas, F. 2001: Mjølnir (Barents Sea) meteorite impact ejecta offers a VolgianRyazanian boundary marker. Newsletter on Stratigraphy 38, 129-140. https://doi.org/10.1127/nos/38/2001/129.

Smelror, M., Dypvik, H. \& Mørk. A. 2002: Phytoplankton blooms in the Jurassic-Cretaceous boundary beds in the Barents Sea possibly induced by the Mjølnir impact. In Buffetaut, E. \& Koeberl, C. (eds.): Geological and Biological Effects of Impact Events, Springer-Verlag, Berlin, pp. 69-81. https://doi.org/10.1007/978-3-642-59388-8_4.

Smelror, M., Petrov, O., Larssen, G.B. \& Werner, S.C. (eds.) 2009: Geological History of the Barents Sea: Atlas. Geological Survey of Norway, Trondheim, $135 \mathrm{pp}$.

Smith, D.G. 1974: Late Triassic pollen and spores from the Kapp Toscana Formation, Hopen, Svalbard. A preliminary account. Review of Palaeobotany and Palynology 17, 175-178. https://doi.org/10.1016/0034-6667(74)90098-0.

Smith, D.G. 1982: Stratigraphic significance of a palynoflora from ammonoid-bearing Early Norian strata in Svalbard. Newsletter on Stratigraphy 11, 154-161. https://doi.org/10.1127/nos/11/1982/154.

Smith, D.G., Harland, W.B. \& Hughes, N.F. 1975: The geology of Hopen, Svalbard. Geological Magazine 112, 1-23.

https://doi.org/10.1017/S0016756800045544.

Smith, D.G., Harland, W.B., Hughes, N.F. \& Pickton, C.A.G. 1976: The geology of Kong Karls Land, Svalbard. Geological Magazine 113, 193-304. https://doi.org/10.1017/S001675680004320X.
Tegner, C., Stolbov, N.H., Svensen, H., Brown, E.L. \& Planke, S. 2015: Cretaceous magmatism of Svalbard and Franz Josef Land: Petrogenesis of the High Arctic Large Igneous Province. $7^{\text {th }}$ International Conference of Arctic Margins - ICAM 2015, Abstract. NGU Report 2015.032, 136 pp.

Verdenius, J.G. 1978: A Valanginian calcareous nannofossil association from Kong Karls Land, Eastern Svalbard. Norsk Polarinstitutts Årbok 1977, 350-352.

Vigran, J.O., Mangerud, G., Mørk, A., Bugge, T. \& Weitschat, W. 1998: Biostratigraphy and sequence stratigraphy of the Lower and Middle Triassic deposits from the Svalis Dome, Central Barents Sea, Norway. Palynology 22, 89-141.

https://doi.org/10.1080/01916122.1998.9989505.

Vigran, J.O., Mangerud, G., Mørk, A., Worsley, D. \& Hochuli, P. 2014: Palynology and geology of the Triassic succession of Svalbard and the Barents Sea. Geological Survey of Norway Special Publication 14, $1-270$.

Wierzbowski, A. \& Århus, N. 1990: Ammonite and dinoflagellate cyst succession of an Upper Oxfordian-Kimmeridgian black shale core from the Nordkapp Basin, southern Barents Sea. Newsletter on Stratigraphy 22, 7-19. https://doi.org/10.1127/nos/22/1990/7.

Woollam, R. \& Riding, J.B. 1983: Dinoflagellate cyst zonation of the English Jurassic. Institute of Geological Sciences Report 83/2, 44 pp.

Worsley, D. 1973: The Wilhelmøya Formation - a new lithostratigraphic unit from the Mesozoic of Eastern Svalbard. Norsk Polarinstitutts Årbok 1971, 7-16.

Worsley, D. 2008: The post-Caledonian development of Svalbard and the western Barents Sea. Polar Research 27, 298-317. https://doi.org/10.1111/j.1751-8369.2008.00085.x.

Worsley, D., Johansen, R. \& Kristensen, S.E. 1988: The Meozoic and Cenozoic succession of Tromsøflaket. In Dalland, A., Worsley, D. \& Ofstad, K. (eds.): A lithostratigraphic scheme for the Mesozoic and Cenozoic succession offshore mid-and northern Norway, Norwegian Petroleum Directorate Bulletin 4, pp. 42-65.

Zakharov, V.A. 1981: Buchiids and biostratigaphy of the Boreal Upper Jurassic and Neocomian. Trudy, Instituta Geologii i Geofiziki, Akademiya Nauk SSSR, Sibirskoe Otdelenie 458, 280 pp.

Århus, N. 1988: Palynostratigraphy of some Bathonian-Hauterivian sections in the Arctic, with emphasis on the Janusfjellet Formation type section, Spitsbergen. Institutt for Kontinentalsokkelundersøkelser (IKU) Report 23.1252.11/01/88, 139 pp.

Århus, N. 1991: Dinoflagellate cyst stratigraphy of some Aptian and Albian sections from North Greenland, southern Spitsbergen and the Barents Sea. Cretaceous Research 12, 209-225. https://doi.org/10.1016/0195-6671(91)90035-B.

Århus, N. 1992: Some dinoflagellate cysts from the Lower Cretaceous of Spitsbergen. Grana 31, 305-314. https://doi.org/10.1080/00173139209429453.

Århus, N., Kelly, S.R.A., Collins, J.S.H. \& Sandy, M.R. 1990: Systematic paleontology and biostratigraphy of two Lower Cretaceous condensed sections from the Barents Sea. Polar Research 8, 165-194. https://doi.org/10.3402/polar.v8i2.6811. 